\title{
Comparison of medicinal plant knowledge between rural and urban people living in the Biosphere Reserve "Bioma Pampa-Quebradas del Norte", Uruguay: an opportunity for biocultural conservation
}

Elena Castiñeira Latorre ${ }^{1,2}$; Andrés Canavero3; María Lelia Pochettino ${ }^{1,4}$

\begin{abstract}
The Biosphere Reserve, UNESCO, "Bioma Pampa-Quebradas del Norte", Rivera Department is an important reservoir of biocultural diversity of Uruguay. With the objective of contributing to its recognition and valuation, we describe the diversity of medicinal plants used by local communities in rural or urban settlements at the Reserve, from a quali-quantitative ethnobotanical approach. We estimated and compared species richness of alien and native medicinal plants mentioned by the 13 urban and 31 rural people in semi-structured interviews selected by snowball sampling. We found that the diversity of medicinal plants comparing urban and rural areas did not present significant differences. However, rural areas report more native species as consequence of a higher environmental offer of medicinal plants and the prevalence of cultural elements of native peoples; in contrast, the construction of homegardens within a pluricultural context in urban areas promotes the incorporation of alien species in the local herbalist. Finally, we emphasize the possibility of integrating the official medicinal system with the traditional medicinal systems based in plants, contributing to the programs of conservation of biocultural heritage and primary health care as posed by the World Health Organization in its Traditional Medicine Strategy 2014-2023.
\end{abstract}

Keywords: Ethnobotany; Medicinal Plants; Traditional Knowledge; Alien Species; Rarefaction Curves; Protected Areas.

\footnotetext{
${ }^{1}$ Laboratorio de Etnobotánica y Botánica Aplicada, Facultad de Ciencias Naturales y Museo, Universidad Nacional de La Plata, 1900 La Plata, Buenos Aires, Argentina.

2 Grupo de Investigación y Formación en Recursos Humanos en Biodiversidad, Centro Universitario Regional Este, CURE, Maldonado, Uruguay (CURE).

${ }^{3}$ Departamento de Ecología y Gestión Ambiental, Centro Universitario Regional Este, Universidad de la República, Maldonado, Uruguay (CURE).

${ }^{4}$ CONICET, Argentina.
}

* Corresponding author. $\square$ E-mail address: Elena Castiñeira Latorre, elencasti@gmail.com 


\section{INTRODUCTION}

The biocultural diversity is defined by Maffi (2007) as "the diversity of life in all its manifestations: biological, cultural, and linguistic - which are interrelated (and possibly coevolved) within a complex socioecological adaptive system". The conservation of biocultural heritage ensures an increase in the resilience of these systems (Ferreira Júnior et al. 2015; Folke et al. 2010; Gavin et al. 2015; Maffi and Woodley 2010). A relevant dimension of biocultural diversity is expressed in the botanical knowledge of communities (Hurrell 2014; Hurrell and Pochettino 2014; Lozada et al. 2006; Reyes-Garcia et al. 2009; Santoro et al. 2015).

Uruguay presents an interesting
governance configuration for the
development of ethnobotany applied to biocultural diversity conservation and in particular if the focus is on botanical medicinal systems (Maffi and Woodley 2010). In this sense, one important fact is the implementation of the National System of Protected Areas (SNAP-for its initials in Spanish, law $n^{\circ} 17.234$ of the constitution of Uruguay). One particularity of the SNAP is its insertion on private immovable property that is occupied by productive activities (e.g. farming, cattle raising, afforestation). Therefore, to conciliate productive and conservation interests, it uses a governance model made up of local and state actors. This allows an integral management of the diverse objectives present in the territory. The other fact is the recently initiated health reform under an integral perspective (Fuentes 2010; Sollazzo and Berterretche 2011), based on the principles of Alma Ata, and in a renewed Primary Health Care (WHO 2013). The principles of Alma-Ata agreed in the International Conference on
Primary Health Care in 1978, "expressing the need for urgent action by all governments, all health and development workers, and the world community to protect and promote the health of all the people of the world". "Primary health care is essential health care based on practical, scientifically sound and socially acceptable methods and technology made universally accessible to individual and families in the community through their full participation and at a cost that the community and country can afford to maintain at every stage of their development in the spirit of selfreliance and selfdetermination" (Declaration of Alama-Ata, 1978) (WHO 2013). The health reform aims to address biopsychosocial, community and environmental particularities, recognizing further that the physician is not the "only knowledge". In this sense, the reform includes the formation of community health teams made up of doctors, nurses, social workers, psychologists and community referrals (Sollazzo and Berterretche 2011, WHO 2013).

While in the majority of the territory of Uruguay there is broad coverage of biomedical health care and access to industrialized medicines (Cardona et al. 2013), it has been reported, as at other localities in the region (e.g. Hilgert 2009), that people resort to mixed systems incorporating the biomedical and the one based on medicinal plants for the health care (Alonso Paz et al. 2008). This knowledge is framed in a pluricultural context of the area, which is enabled by diverse migratory flows of native Amerindian, Africans and Europeans (Bonilla et al. 2004; Curbelo 2003; González and Rodríguez Varese 1990; Pellegrino 2013), along with an environmental offer of native and alien species that varies between urban and rural environments (Abreu et al. 2015; Janni and 
Bastien 2004; Martínez and Pochettino 1992; Rossato et al. 1999).

Understanding how people choose and integrate certain botanical resources into the health care system is a central theme in ethnobotanical studies (Albuquerque et al. 2013). In this regard, several authors try to understand how interacts people with plant diversity and if the environment can influence the incorporation of particular botanical medicinal resources. In this line has been reported a strong representativeness of alien plants in local pharmacopoeias in different areas of the globe (e.g. Alencar et al. 2010; Begossi et al. 2002; Bennett and Prance 2000; Medeiros 2013; Medeiros et al. 2012). It is suggested that the incorporation of exotic plants may comes from a set of intrinsic characteristics of the species, such as: colonization capacity (Begossi et al. 2002) and utilitarian versatility (Alencar et al. 2010), as well as cultural factors related to the environment (e.g. rural, urban) where various processes affect, among them: immigration, modernization (e.g. Leonti 2011; Leonti et al. 2010), acculturation (the loss of native or ancestral knowledge, Eyssartier et al. 2008; Ramirez 2007; Vandebroek and Balick 2012), appearance of new ailments (e.g. Vandebroek and Balick 2012) and generation of innovative therapeutic knowledge (e.g. diversification hypothesis, see Albuquerque 2006). In this sense, this work contributes to the theoretical reflection and to the strategic objectives of the World Health Organization 2014-2023 (WHO 2013), to health reform (Fuentes 2010; Sollazzo and Berterretche 2011) and the SNAP (www.mvotma.gub.uy/snap).

This work describes the diversity of medicinal plants (species richness) used by local communities in the Biosphere Reserve "Bioma Pampa-Quebradas del Norte",
Rivera Departament, Uruguay. From a quantitative approach, it is described, estimated and compared the knowledge about alien and native medicinal plants, in terms of species richness, mentioned by the urban and rural communities of the Reserve. The finding of a pharmacopoeia composed of greater presence of alien plants in urban environments and native in rural one, it is discussed in relation to pluricultural and environmental contexts. Finally, emphasis is placed on the possibility of integrating official and traditional medicine systems with medicinal plants, contributing to the programs of conservation of biocultural heritage and primary health care.

\section{MATERIAL AND METHODS}

\section{Study area}

In the year 2011, 110.882 hectares of Rivera Department, Uruguay, is declared: "UNESCO Reserve Biosphere", under the name "Bioma Pampa-Quebradas del Norte" (Fig. S1, supplementary material). The Biosphere Reserve, UNESCO, "Bioma Pampa-Quebradas del Norte", which contains the protected area "Valle del Lunarejo"-SNAP, is located in the Rivera Department and is one of the most important reservoirs of biodiversity of Uruguay (Brussa and Grela 2007; Soutullo et al. 2013). The area extends over the northwest of the department, from the departmental boundary of Tacuarembó to the border with Brazil. The Reserve presents an important number of springs of a fluvial network associated to the set of blades and ravines. On the margins of these watercourses riparian mounts of high diversity are developed, similar to that of Atlantic subtropical forests, with an herbaceous stratum of high plant richness of families Poaceae, Fabaceae, Orchidaceae y 
Asteraceae (Brussa and Grela 2007). Given the richness of plants that makes up the area, this area has been recognized as of interest for conservation (DINAMA 1998; Gautreau and Lezama 2009; Grela and Romero Suárez 1996; Sayagues et al. 2000; Soutullo et al. 2013). In addition to the biodiversity conservation aspects, the objectives of the reserve include reinforcing the cultural traditions associated with the particularity of the inhabitants of rural areas (DINAMA 1998, 1999; MVOTMA 2017). The climate is warm temperate or subtropical, and corresponds to category Cfa according to the classification of Köppen-Geiger (Kottek et al. 2006; Rubel and Kottek 2010).

\section{Population characteristics}

A synthesis of the settlement of the current Uruguayan territory must show an extensive temporal sequence initiated at least 9000 BC years ago, under a dynamic of establishment, change and replacement of successive waves of different groups of native people. This includes nomadic groups of hunter-gatherers belonging to a possible macroethnic group "charrúa", higher technical development groups related to cultural groups of Patagonian and Paraná connection (Pi Hugarte 2014). These indigenous populations suffered profound alterations with the arrival of Europeans in the Rio de la Plata. These groups were mostly converted and assimilated by the missionaries. It is important to emphasize the importance of the Guarani missionary natives in the development of this process, which led to the disappearance of most ethnic groups, with the exception of some groups that they resisted and later were exterminated, the great part of the descendants of the original peoples were incorporated into the "Creole" society (i.e. direct descendants of Europeans born in Uruguay) (Pi Hugarte 2014).

Subsequently, in the eighteenth and nineteenth centuries the actual Uruguayan territory was characterized by the populating of the rural land mainly by families of Spanish immigrants coming from Montevideo (Barrios Pintos 1963, 1990; Pi Hugarte and Vidart 1969). The population would later become an amalgam of diverse Amerindian, European and African cultures (Bonilla et al. 2004), composed of descendants of native peoples (mainly Guaraní natives), Spaniards, Basques, French, Germans, and West Africans (Curbelo 2003; González and Rodríguez Varese 1990), configuring a pluricultural context (sensu Martínez et al. 2006). The Rivera Department has a population of approximately 100,000 inhabitants (INE 2011). More than a quarter of the people living in the semi-urban area of the city of Rivera carry out agricultural activities on family farms with less than 40 hectares, where they develop their activities with a low investment capacity. The production units market their products directly in the nearest populated centers. The item requires investment in infrastructure, technical knowledge and access to the market, so the activity is conceived as self-consumption and sale of surplus, without capitalization achievements (Nolla and de Vargas 2010; Rodriguez Miranda 2010).

\section{Election of interlocutors and interview development}

The prospecting work began in 2012 in the city of Rivera, with the aim of identifying the community referents of medicinal botanical knowledge. The following year tasks began with the identification and the interviews of the 44 interlocutors, which was 
a posteriori divided into two categories: a) sellers of medicinal plants characterized by knowledge about medicinal plants and associated treatments y b) people recognized in the local community for their medicinal plant knowledge but are not engaged in the marketing of resources or knowledge. This last group was divided into: people living in urban and rural environments (sensu Cardeillac et al. 2016). A "snowball sampling" was performed starting with a seller of medicinal plants, to which a semi-structured interview was carried out and subsequently invited to appoint another member of the target population, this method allowed the generation of a growing sample (Albuquerque et al. 2014; Cunningham 2001; Newman 2010; Noy 2008).

We developed five field trips with medicinal plants sellers to natural harvesting sites, "Valle del Lunarejo" and "Great Britain Park" (PGB), using the participant observation technique/strategy (Albuquerque et al. 2014), and we performed participant observation at courtyards and gardens (sensu Albuquerque et al. 2014). In this way, it was possible to record the vernacular names with the botanical taxonomy of the species. All the interviews were recorded generating audio files along with annotations in field notebooks. The interviews were decoded and a careful interpretation of interlocutors' perception about the diseases, treatments and plants used (emic categories) was carried out. This led to the creation of a categorization (etic categorization) in order to carry out the analyzes (Albuquerque et al. 2014). It should be noted that the methodological approach is in accordance with the ethic principles of the International Society of Ethnobiology (ISE 2014). In this work, we have discussed with each of the interlocutors the "inalienable character" of the information offered by the local population, including the use of recordings and images for exclusive purposes of this work.

Ethnobotanical reference materials were obtained by asking the interlocutors for a sample of each specimen. When medicinal plants were stored, they were determined and subsequently collected at the field sites mentioned by the interlocutors. The botanical reference material collected at its original site was geo-referenced, identified by botanical keys, reference literature and expert consultations (Brussa and Grela 2007; IMM 2000; Lombardo 1973; 1979). Scientific names were corroborated and updated by consulting the following databases: Tropicos (http://www.tropicos.org), Plants Database (USDA, www.plants.usda.gov), Reflora (www.floradobrasil.jbrj.gov.br), Catalog of Vascular Plants of Southern Cone FloraDarwinion Botanical Institute (IBODA, www.darwin.edu.ar). Subsequently, reference specimens were deposited in the Herbarium of the National Museum of Natural History of Montevideo (MNHN) (vouchers numbers: MVM 23201 to 23345) (see Bennett and Balick 2014).

Return activities were carried out for the participating population and residents of the GBP area, consisting in talks on the dissemination of results and the construction of an ethnobotanical herbarium which allows people to appreciate the relationship between biological diversity and medicinal botanical knowledge. Samples of medicinal plants, including the herbarium, remained during the months of September to December of 2014 at the "Environmental Interpretation Center" of the GBP as a return to the community (ISE 2003). 


\section{Statistical analysis}

An incidence matrix was constructed (1=presence, $\quad 0=$ absence) with the interlocutors in the columns $\left(\mathrm{n}_{\mathrm{i}}=44\right)$ and the species in the rows $\left(\mathrm{n}_{\mathrm{spp}}=159\right)$. From this matrix the plant species richness was estimated for the entire study area through the Chao2 index (Colwell et al. 2012; Gotelli and Colwell 2010). Rarefaction curves were performed based on samples (in this case the interlocutors) and allowed to compare communities with different numbers of interlocutors (Colwell et al. 2012; Gotelli and Colwell 2001, 2010; Peroni et al. 2014). Rarefaction curves discriminated the sample by residence of the interlocutors according to whether it corresponded to an urban or rural environment $\left(n_{i}\right.$ urban $\left.=10, n_{i \text { rural }}=34\right)$ and according to the origin of the plant species in native and alien ( $\mathrm{n}_{\mathrm{spp} \text { native }}=87, \mathrm{n}_{\mathrm{spp} \text { alien }}=72$ ). Chao2 indexes were estimated using the "ChaoSpecies" function and the rarefaction curves through the functions iNEXT and ggiNEXT using the $\mathrm{R}$ package "iNEXT" (Hsieh et al. 2016). All analyzes were performed using the $\mathrm{R}$ version 3.03 ( $\mathrm{R}$ Core Team 2017).

\section{RESULTS}

\section{General characterization of the interlocutors interviewed}

Sellers of medicinal plants correspond to a group of men and women who have a wide knowledge on medicinal plants and associated treatments. They are low income people (MTSS 2017), born and raised in rural areas. Although when young they moved to the city to develop commercial activity, they learnt about medicinal plants since childhood as they collaborated with their families identifying and collecting therapeutic resources. Nowadays they perform the collection and trade of medicinal plants like an exclusive activity and of subsistence, they offer their products in the streets and main avenues of the city of Rivera, some of them moving with their baskets and others having fixed places of sale.

Women, in general, are dedicated to the sale as an economic complement to improve their income. They cover various items, such as: selling handicrafts and cosmetics, washing clothes, domestic work and the care of the elderly. They own small homegardens where they grow and harvest the plants that they later dry, fraction and sell. Commercialization is carried out in the homes, consisting of mainly the neighbors as the main buyers, also they offer their products at neighborhood fairs (ex street markets of "Cuaró" in "Rivera Chico" the one of greater dimension and assistance of neighbors). According to the analysis of speech, we infer that when they do not have a medicinal resource demanded in the market, they turn to the male sellers of medicinal plants and make product exchanges.

From the discourse of the interlocutors it has been inferred that they carry out plants and knowledge exchanges with other members of the community. Regarding to this, interlocutors are holders of medicinal botanical knowledge, be or not engaged in the sale of medicinal plants. Those who live in the urban and/or periurban environment, mostly have an education level ranging from complete school to basic high school. They are adult men and women who have been raised in rural areas and young people that have moved to cities (e.g. Rivera and Tranqueras). They have vast knowledge about medicinal plants and associated uses. They usually mention that this knowledge 
was acquired following the teachings of the grandmothers and then supplemented with personal experience and multiple sources of information to which they have access. They usually have an extensive bibliography of consultation on the botanical medicine theme and they search the Internet on natural therapies. These people have in their homes, garden and courtyard crops of some of the medicinal plants that they use and interchange (Fig. 1).

Among the interlocutors that make up the rural group we can distinguish two subgroups. The first corresponds to the rural family, which develops farming and smallscale cow and sheep farming. Their houses are made of bricks, they have electric power and potable water, near the houses there are small subsistence homegardens and in some cases they develop bigger crops of watermelon (Citrullus vulgaris), sweet potato (Ipomoea batatas), tabacco (Nicotiana tabacum), lettuce (Lactuca sativa) and chard (Beta vulgaris var. cicla). Around their dwellings and in the homegardens they cultivate other plants that are used for medicinal purposes.
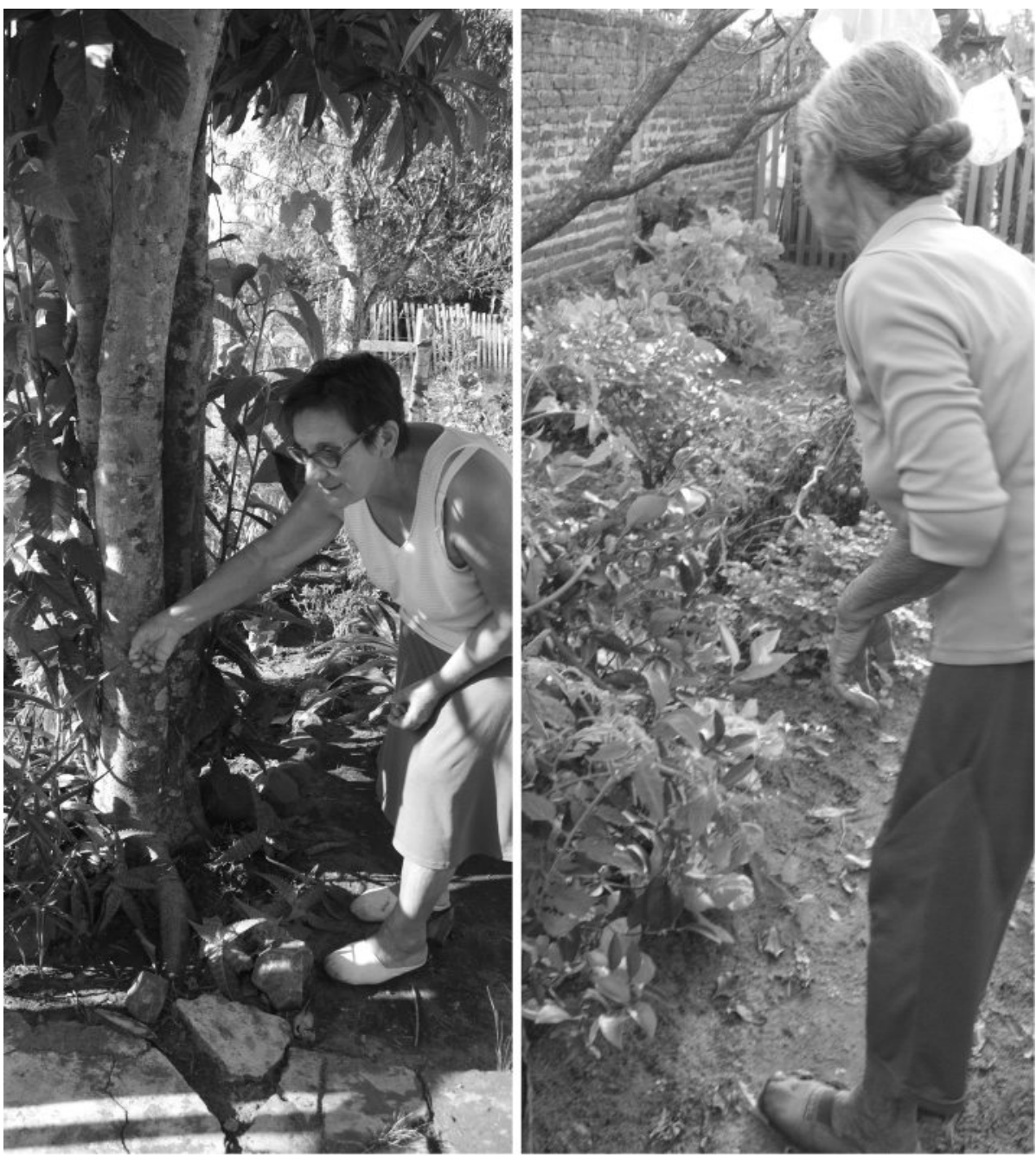

Figure 1: Example of homegardens where people grow some of the medicinal plants they use and exchange. 
The second group corresponds to families dedicated to rural tourism, mainly those families that live inside the Biosphere Reserve. The members of this group generally have a higher education and socioeconomic level. They develop the cattle industry as a complementary activity. Their homes are comfortable, with electricity and drinking water, have Internet connectivity and are prepared to accommodate small groups of tourists. They have extensive material on popular flora and fauna, and show a particular interest in knowing and spreading the medicinal plants that are in their environment.

\section{Sales posts and street sellers}

At the Rivera city we observed fixed stalls and street vendors of medicinal plants, this characteristic is not observed in the rest of the cities of the department (Tranqueras, Corrales Minas, Masoller). Sellers display their products, offer and advise clients on treatments and medicinal properties similar to those performed by pharmacies. There have been no reports of ritual procedures or symbolic actions. The delivery of the product is done in packages of journal paper or white paper; the use of plastic bags was registered in a single opportunity. The approximate size of the branches with leaves and flowers is 15 $\mathrm{cm}$, this allows an easy identification of the product, the approximate weight per package is 50 grams. No particulate material has been observed. The most visible plants at the sales posts and street vending baskets were: Achyrocline satureioides, Ginkgo biloba, Jodina rhombifolia, Malva sylvestris, Matricaria recutita, Mikania periplocifolia, Scutia buxifolia and Stenachaenium campestre (Table 1).

\section{Courtyards and homegardens}

At the courtyards and homegardens daily activities are performed, both of recreation and work related to the preparation and management of the soil, obtaining seedlings and cuttings, seed germination, irrigation, insect management and control, pruning and harvesting (Fig. 1). Specific crops are reported that constitute a mosaic of ornamental, medicinal, aromatic varieties, vegetables, fruit shrubs and plants related to magical aspects. The most reported medicinal plants in these systems were: Aloe spp., Aloysia citrodora, Cestrum euanthes, various species of Citrus spp., Lantana montevidensis, Lippia alba, Malva sylvestris, Lavandula latifolia, Mentha spp., Mikania spp., Plantago tomentosa, Rosmarinus officinalis, Ruta chalepensis. Less frequent were incorporated: Achillea millefolium, Allium sativum, Allium cepa, Artemisia absinthium, Casearia decandra, Casearia sylvestris, Phyllanthus niruri, Tanacetum vulgare, Thymus vulgaris (Table 1).

\section{Harvest sites: "walking and participant observation"}

In the rural area the daily activity of the fieldwork, carried out by men and women is considered by the interlocutors as an opportunity to obtain the medicinal plants. The following species are the most frequently reported in these events: Acanthospermum australe, Arctium lappa, Baccharis articulata, Baccharis trimera, Matricaria chamomilla, Myrceugenia euosma, Usnea sp., Xanthium spinosum (Table 1). On the other hand, the harvest of plants from the riverine forests is performed as a planned activity, usually carried out by men (Fig. 2). In these events it is common the harvest of: Aloysia gratissima, Allophylus 


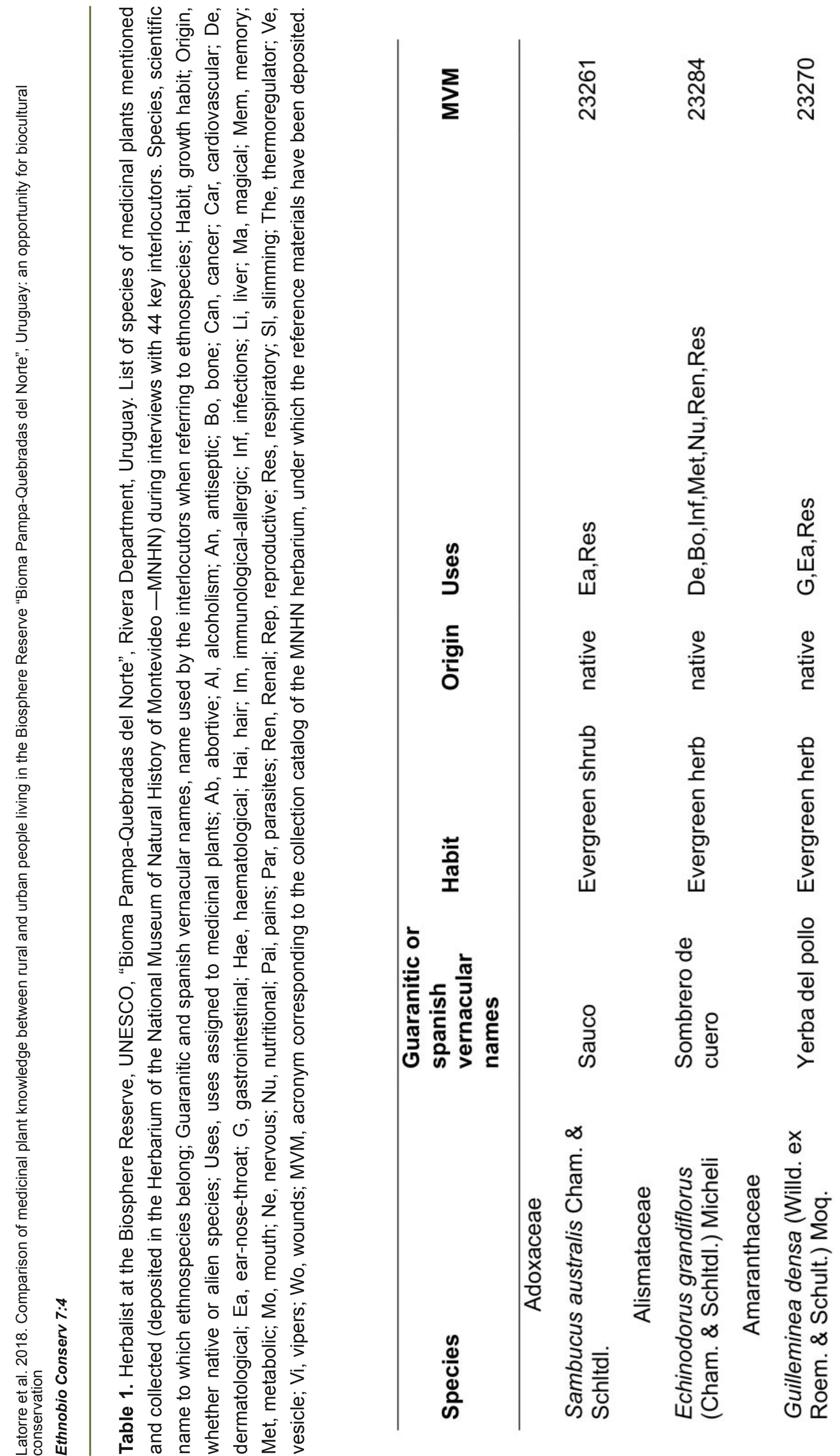




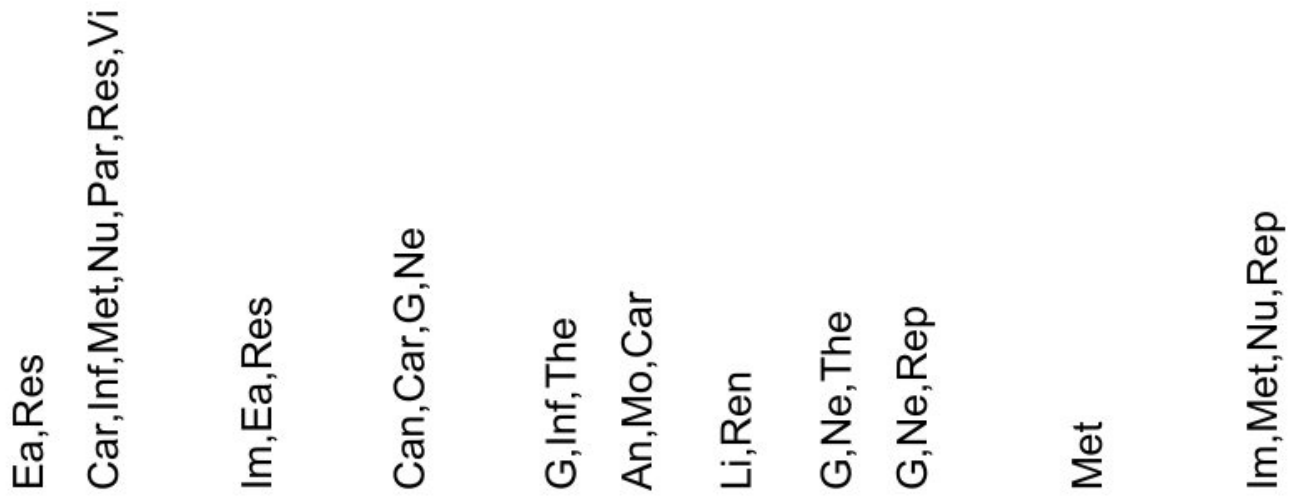

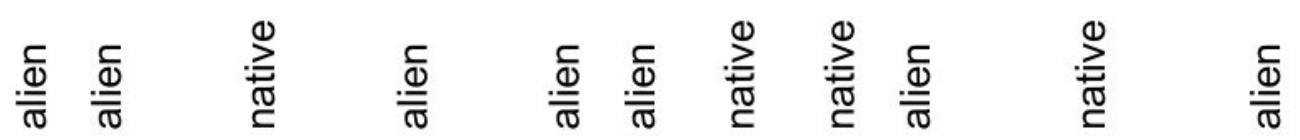

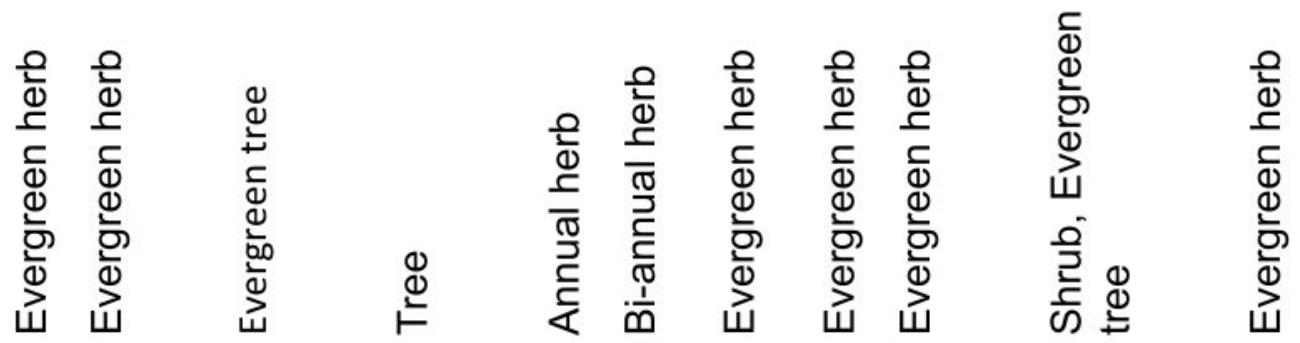

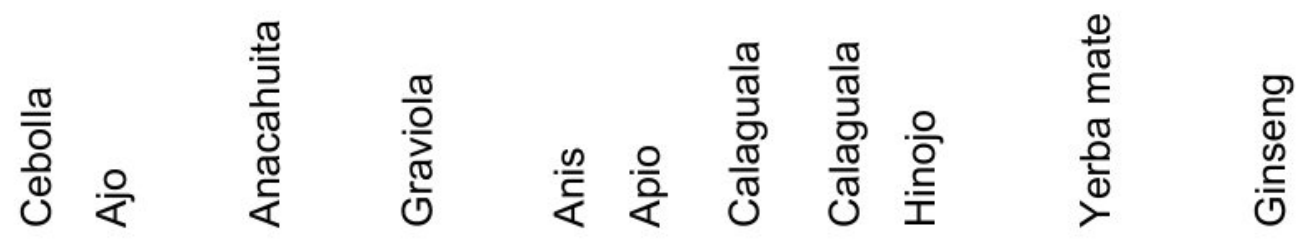

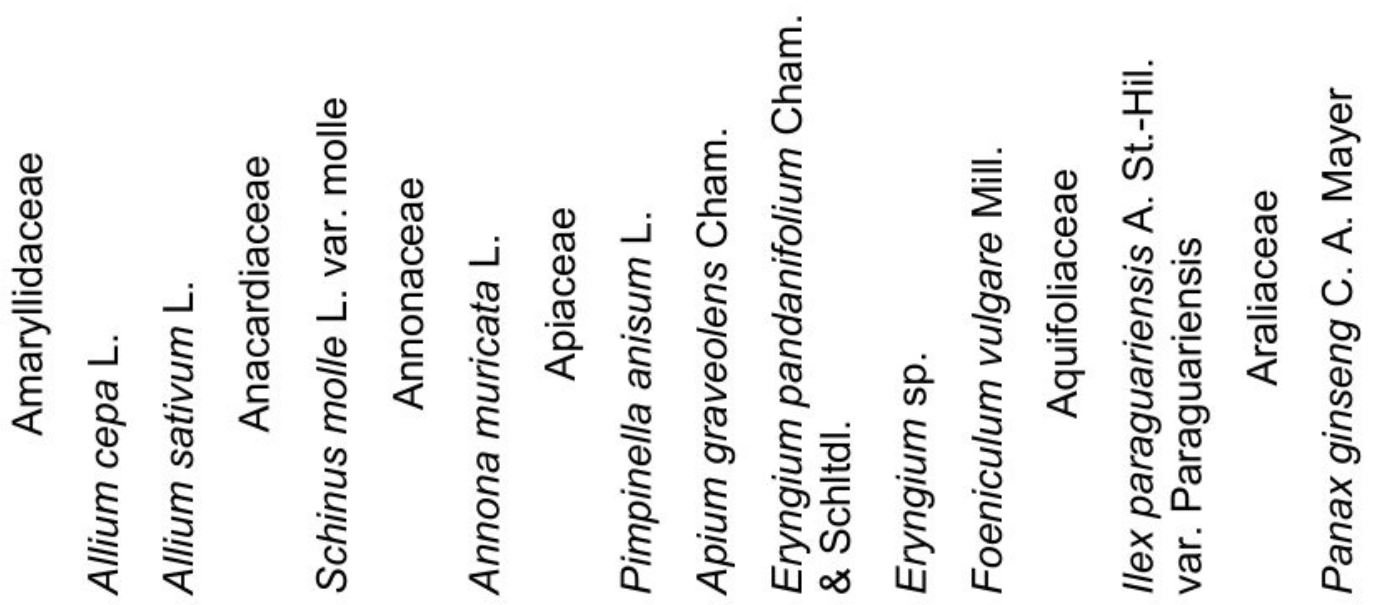




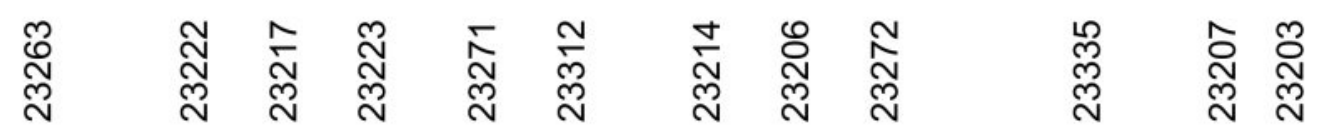

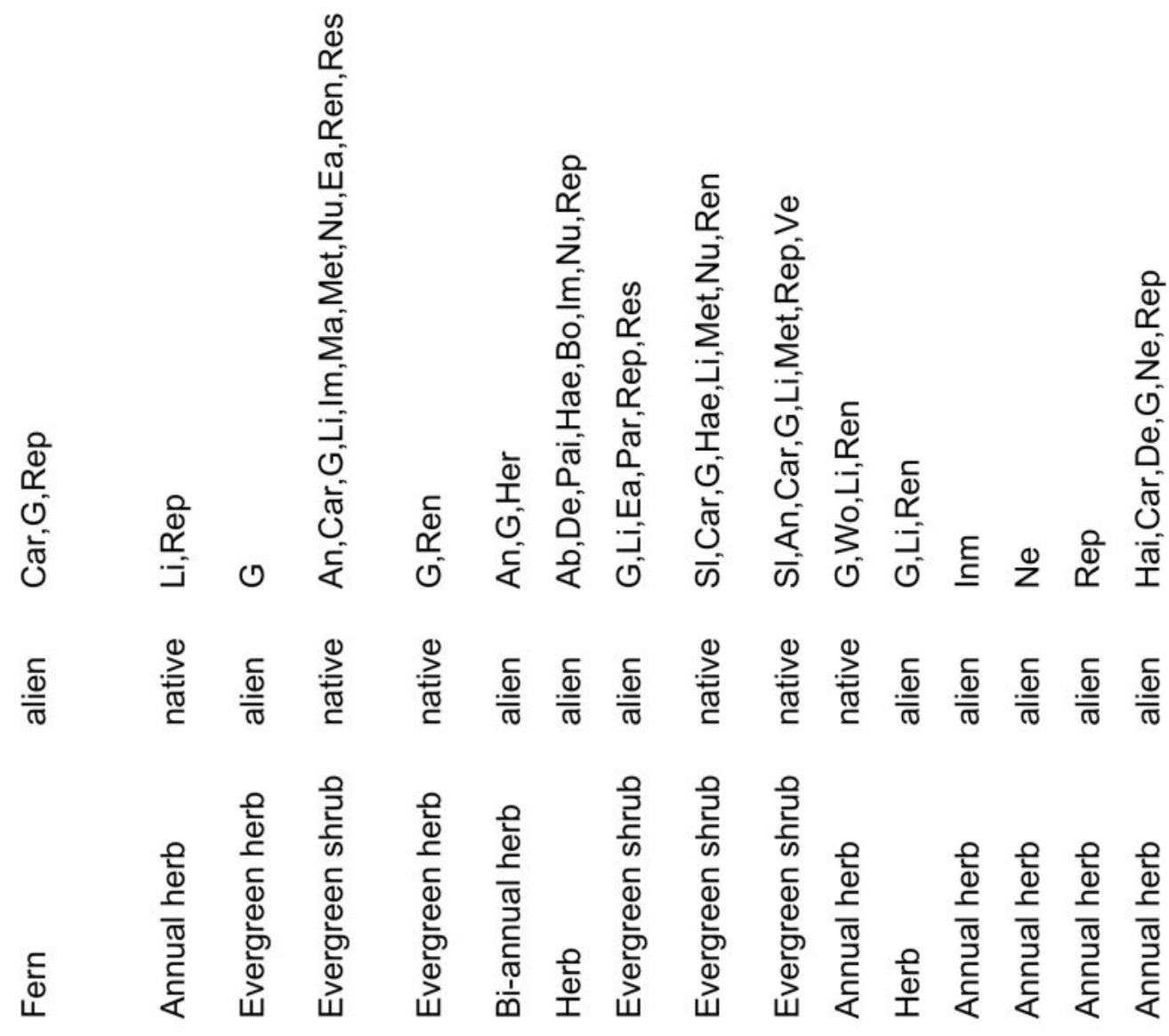

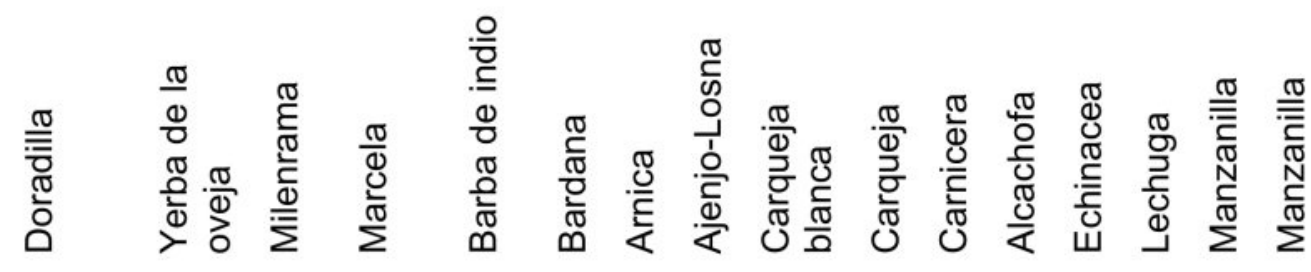

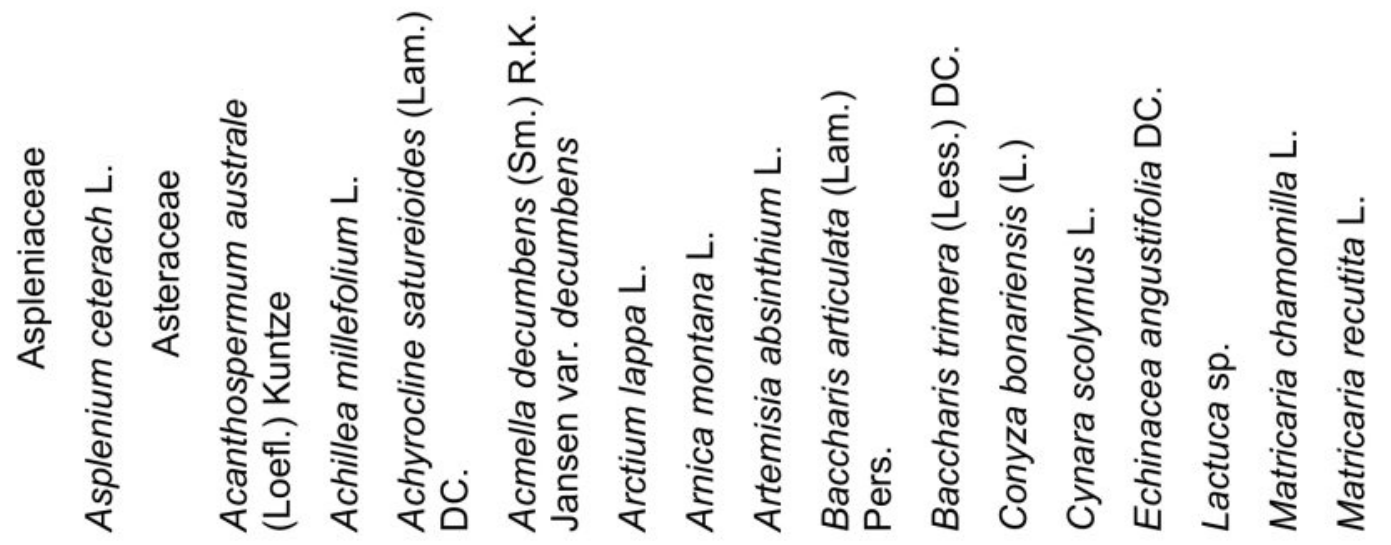




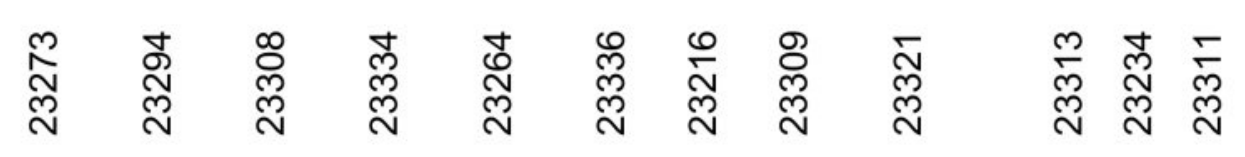

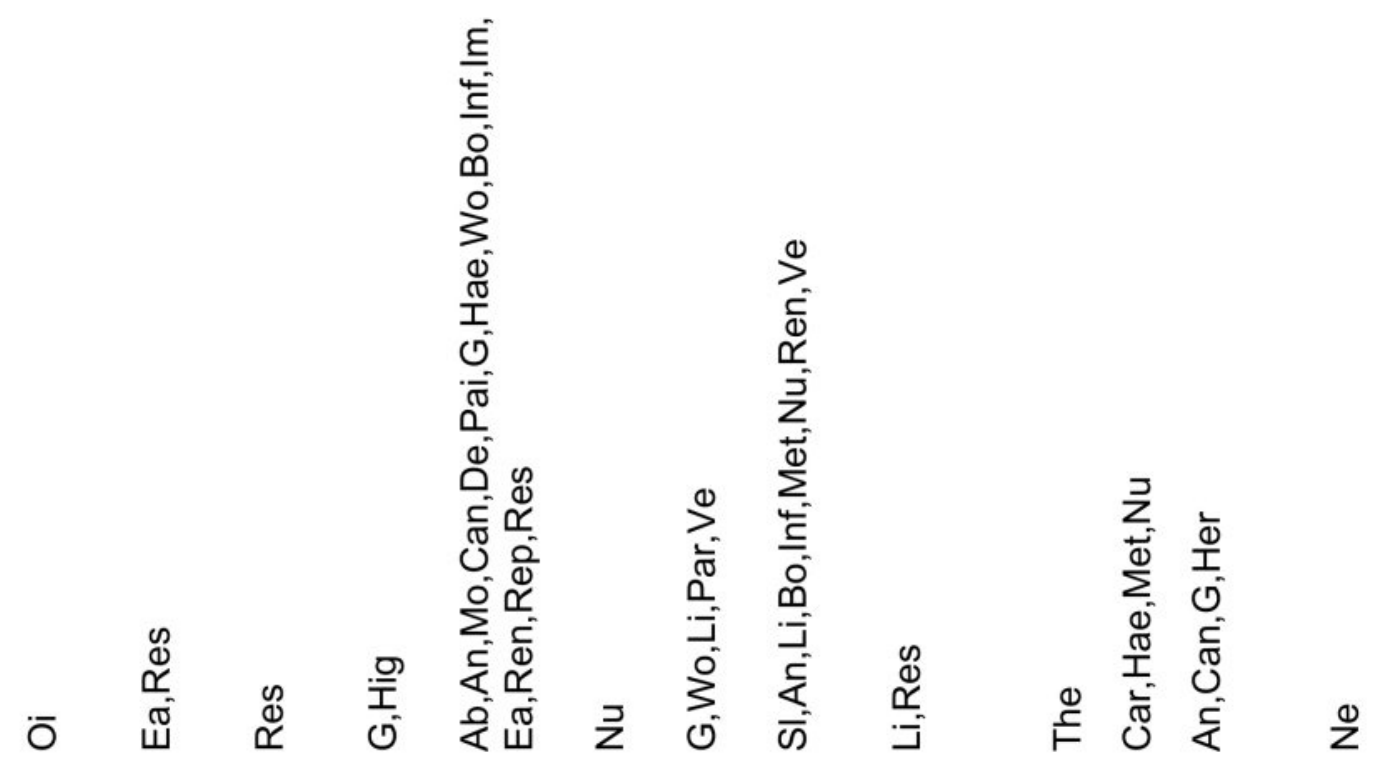

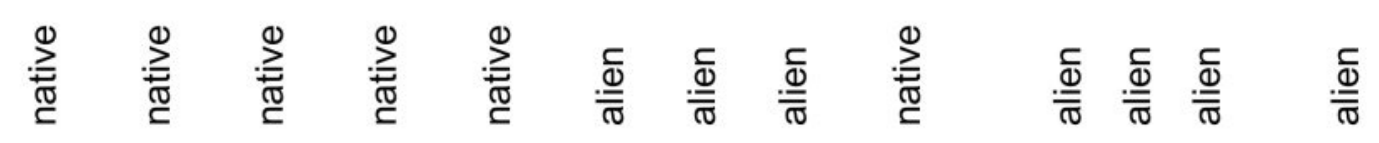

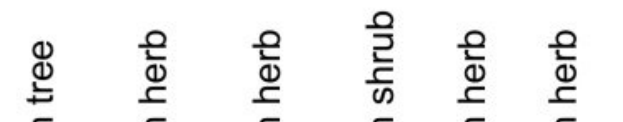

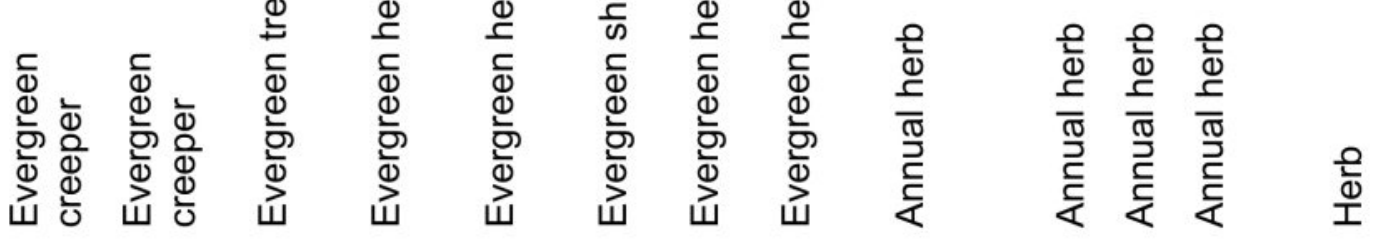

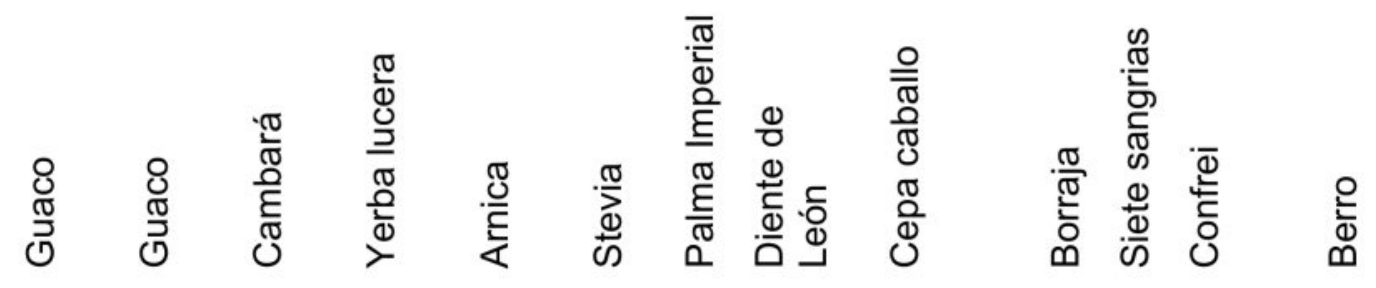

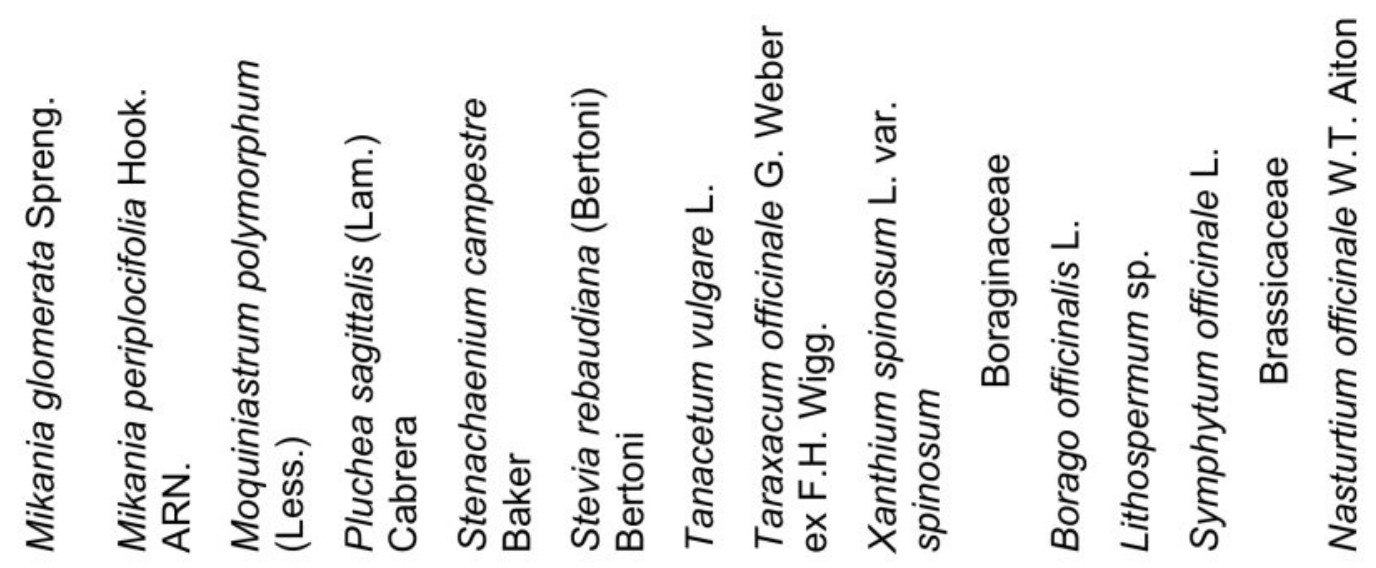




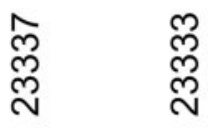

$\begin{array}{lll}\stackrel{0}{0} & \stackrel{0}{N} & \text { N } \\ \text { N } & \text { N } & \text { N }\end{array}$

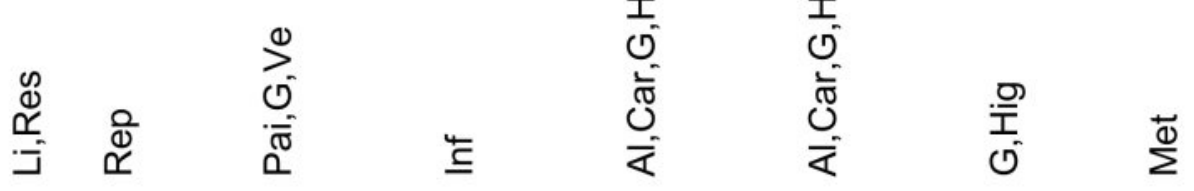

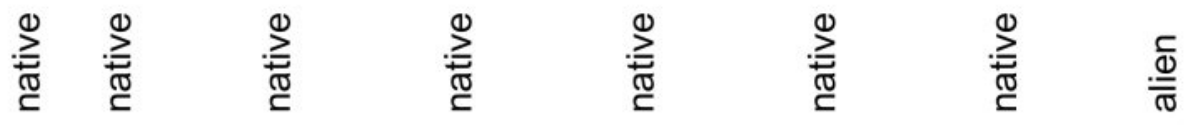

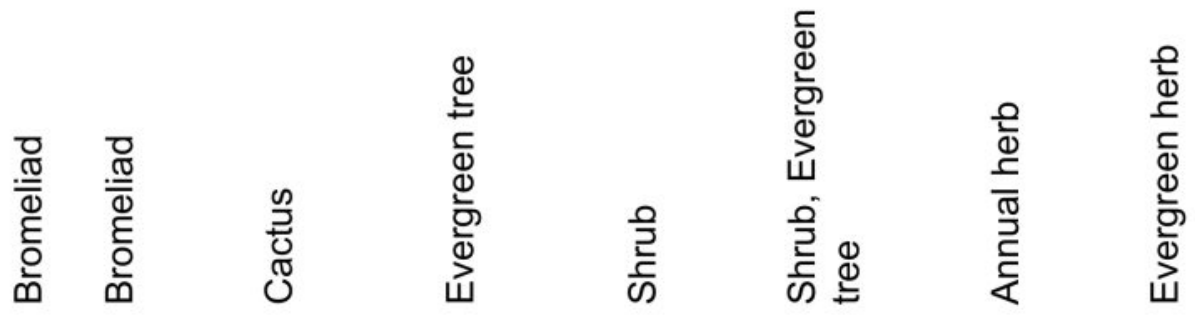

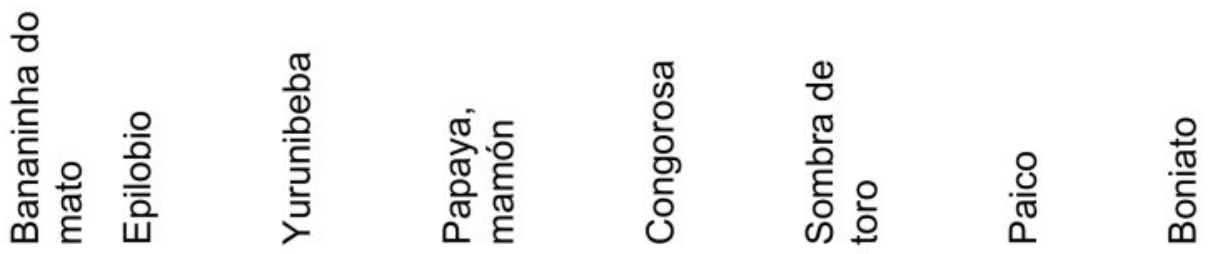

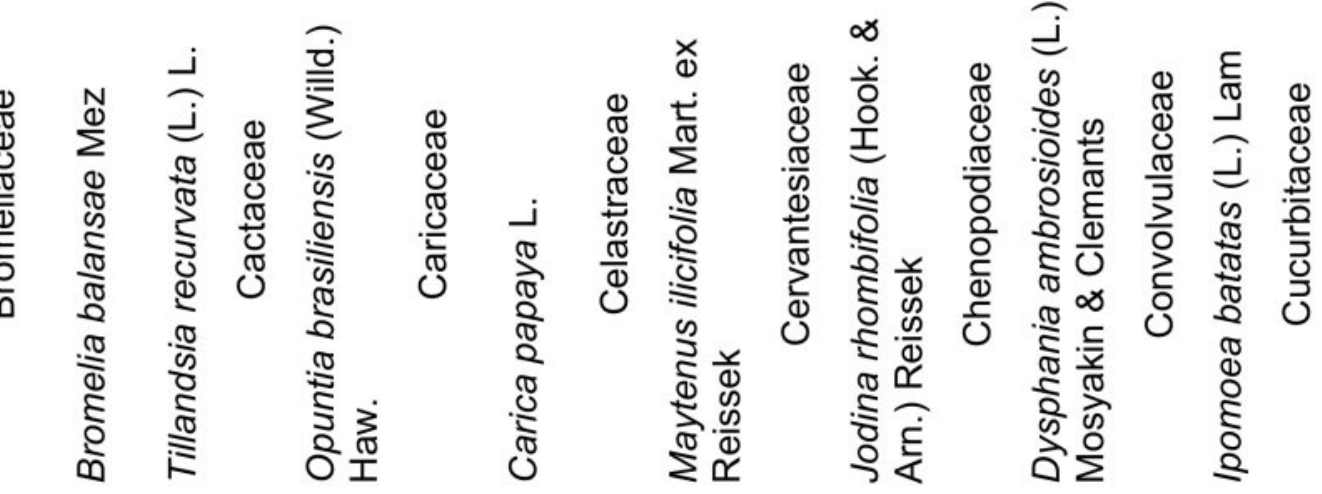



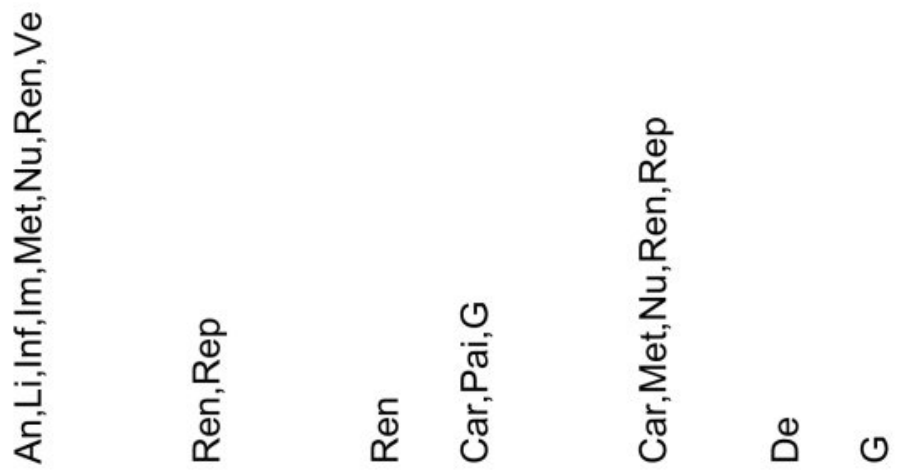

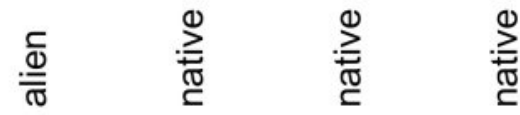

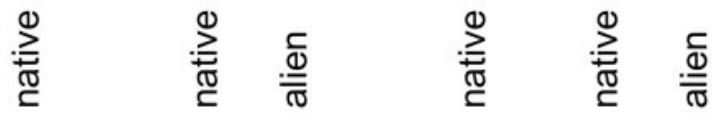

$\frac{\bar{d}}{\frac{0}{10}}$
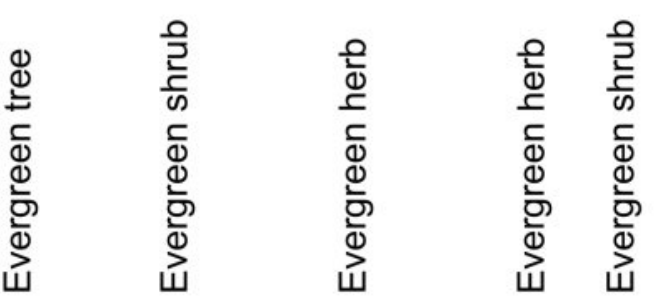

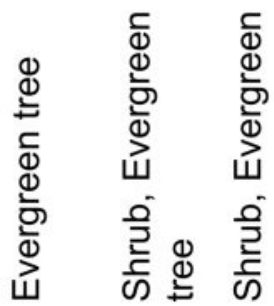

$\begin{array}{ll}\frac{\pi}{\pi} & \frac{\pi}{\pi} \\ \frac{\pi}{\pi} & \frac{\pi}{\pi} \\ \frac{\pi}{\pi} & 0\end{array}$<smiles>C1=CC[SiH]=C1</smiles>

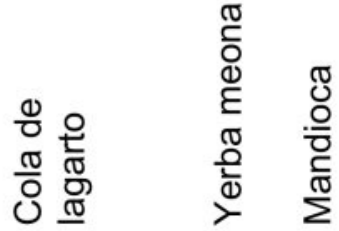

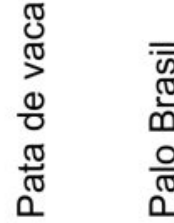

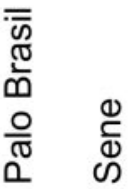

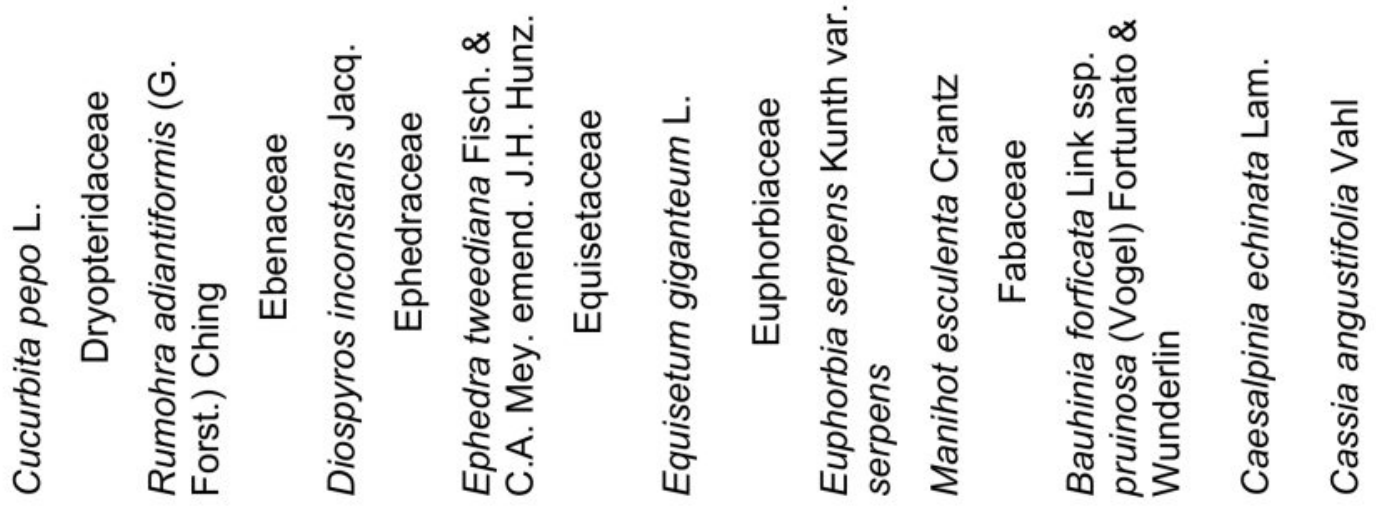

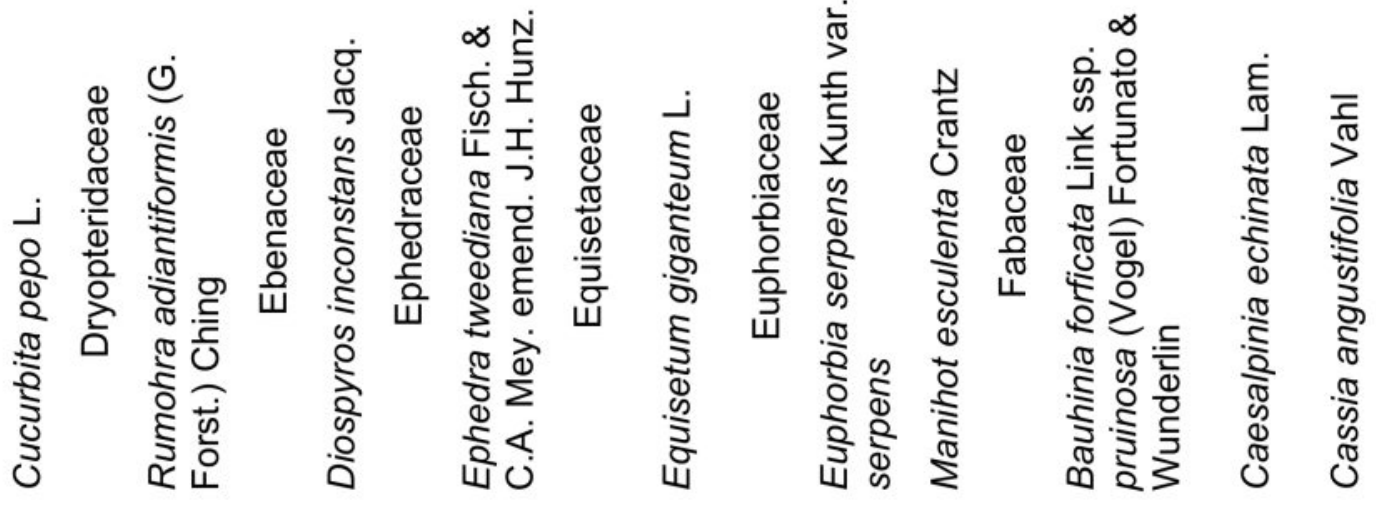


N
N

ণ్ల్లి

लై

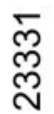

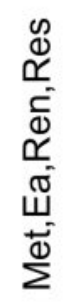

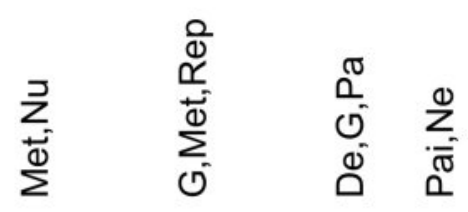

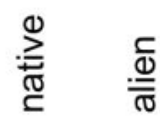

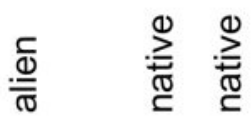

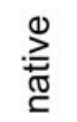

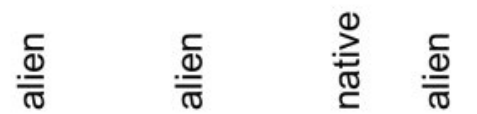

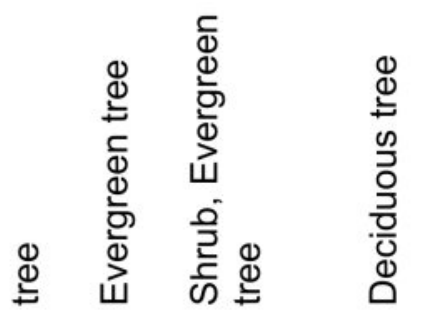

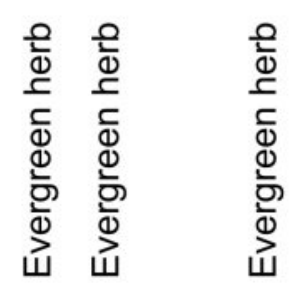

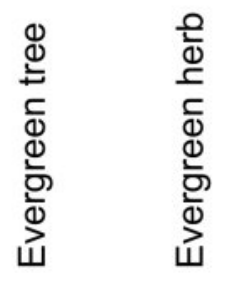

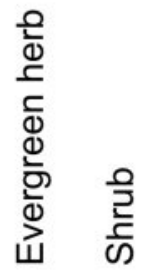

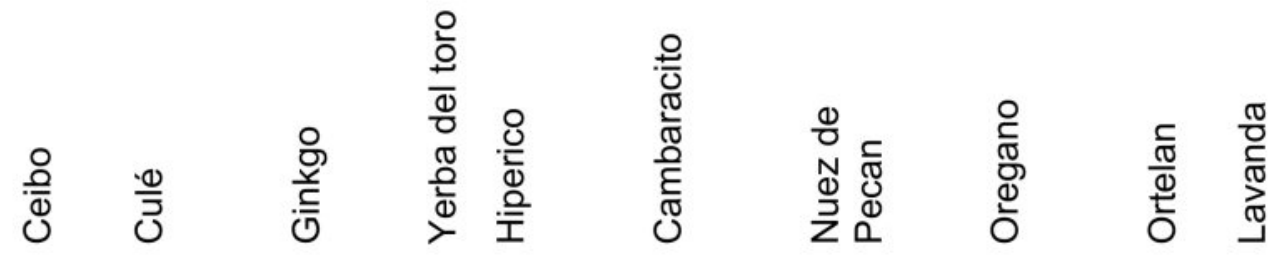

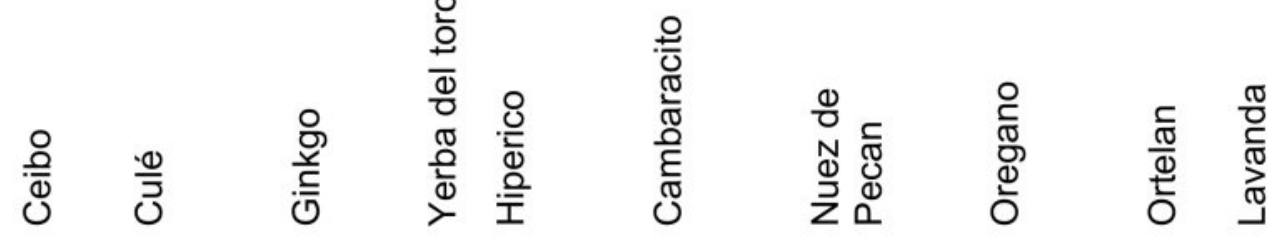

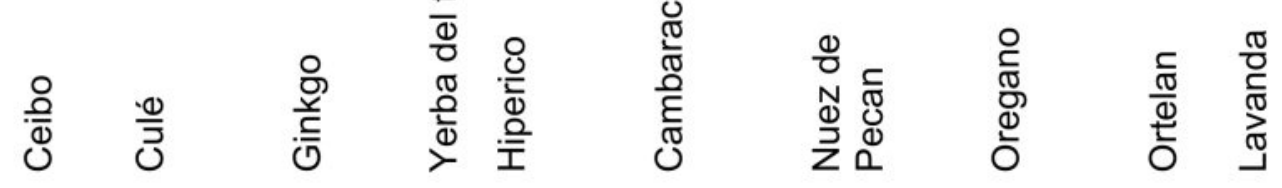

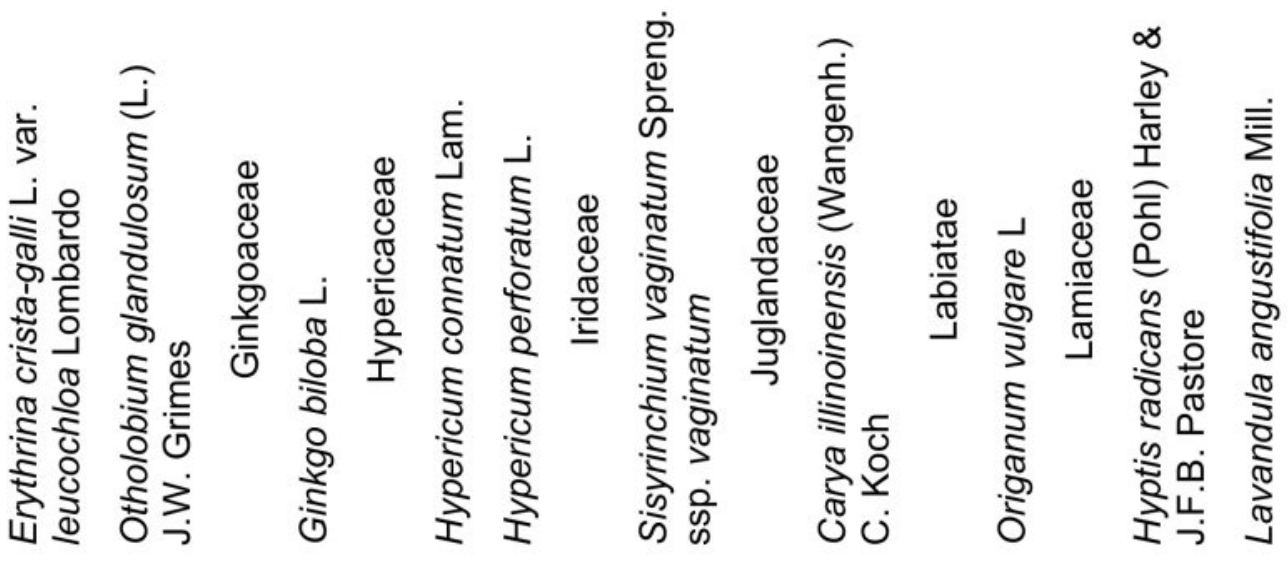




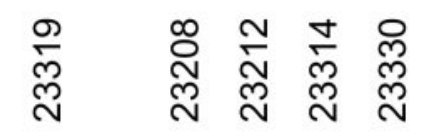

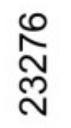

$\begin{array}{lll}N & \mathbb{N} \\ \text { N } & \text { N } & \text { N }\end{array}$

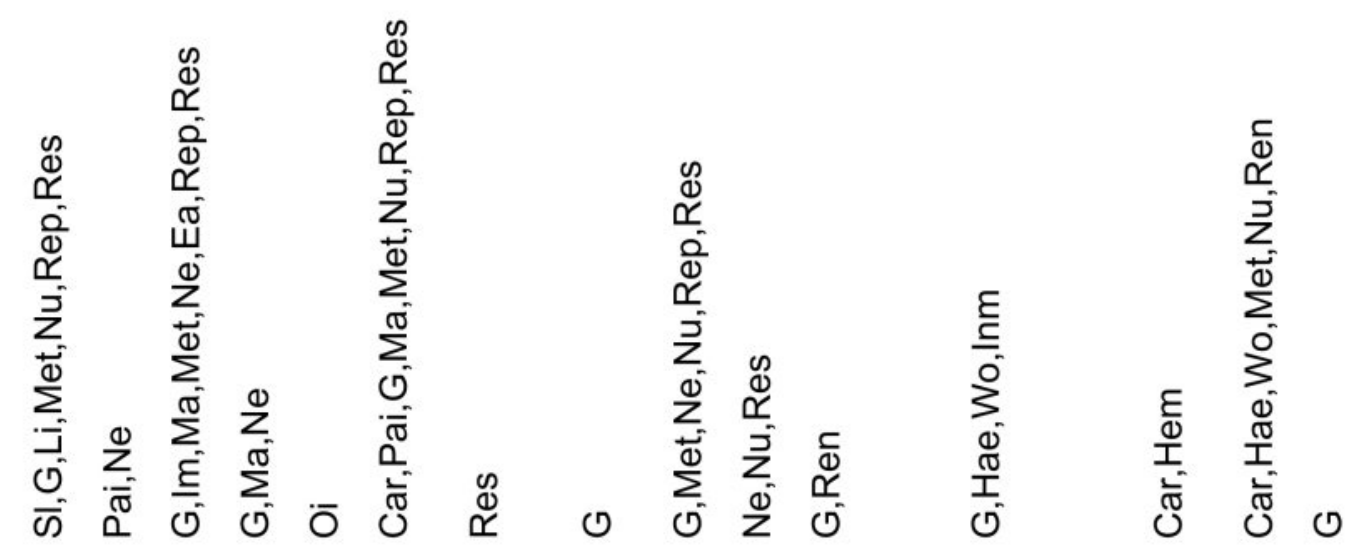

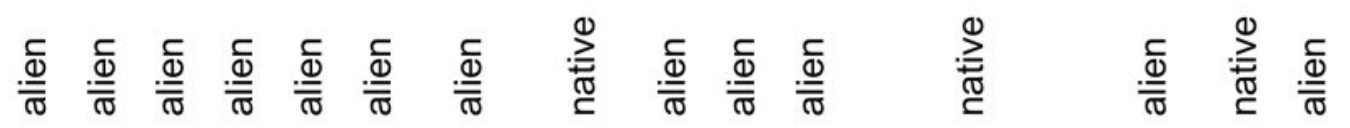

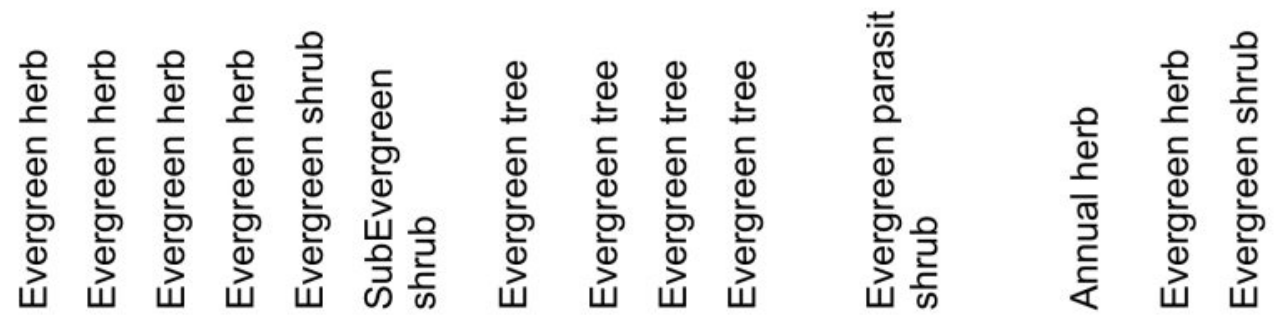

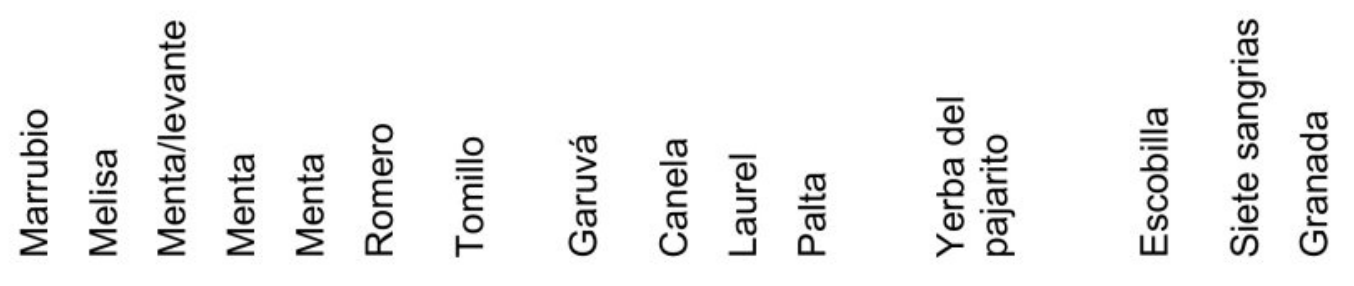

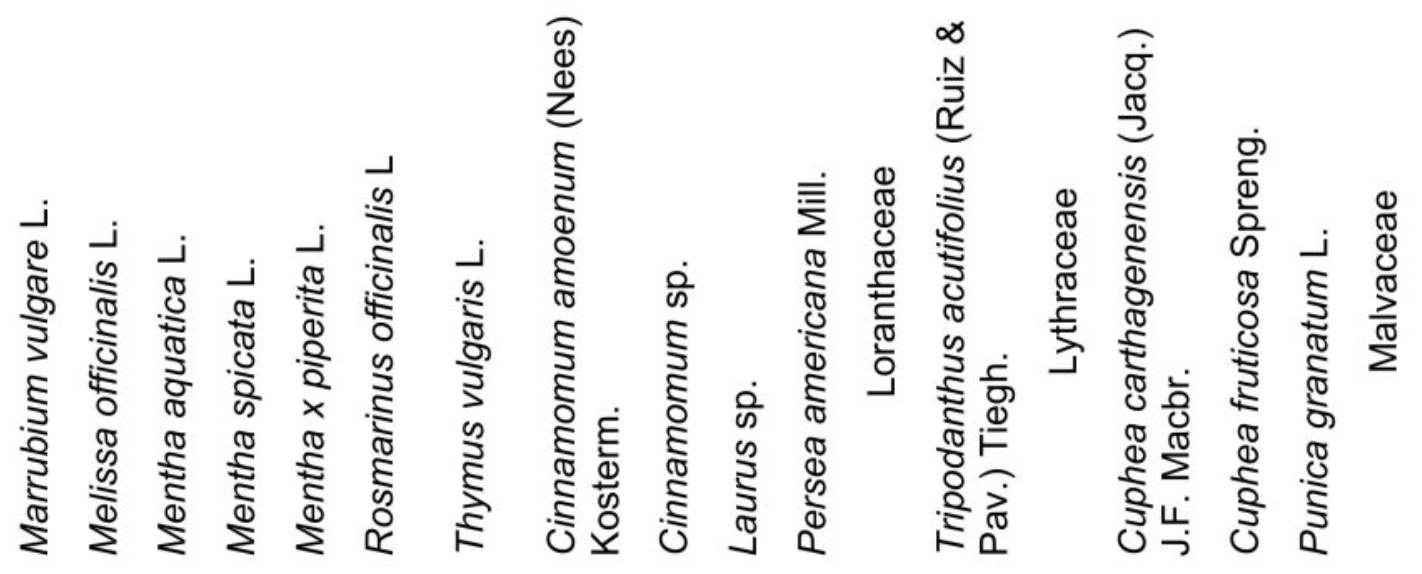




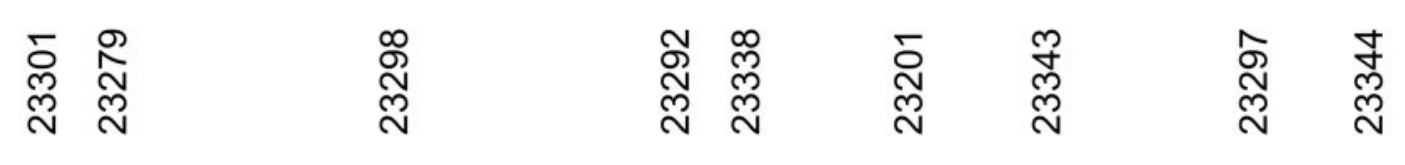

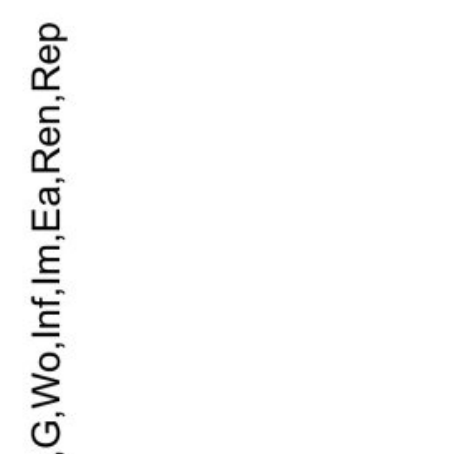

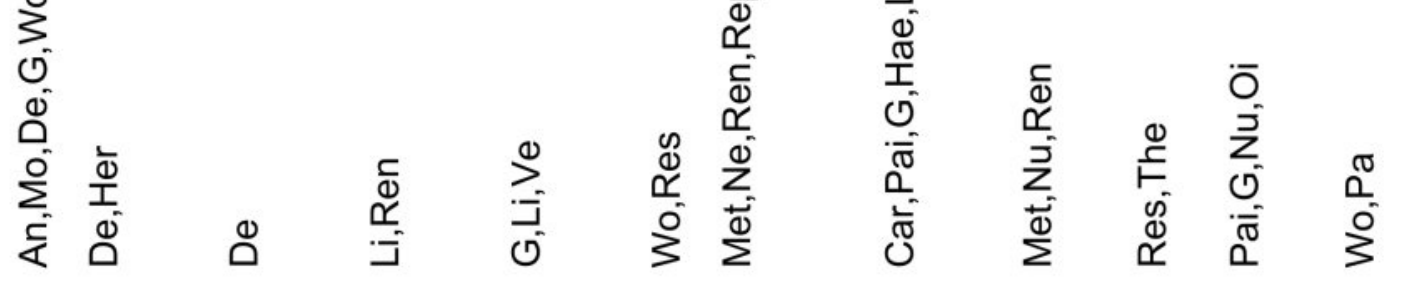

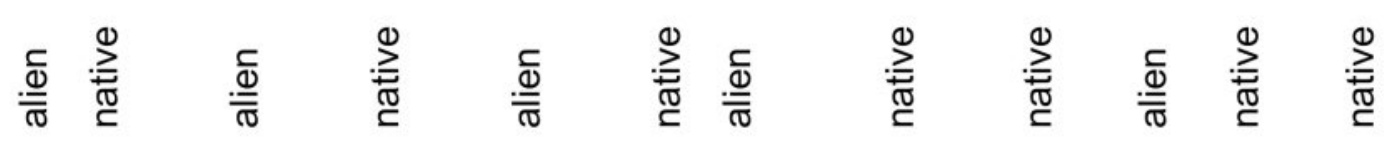

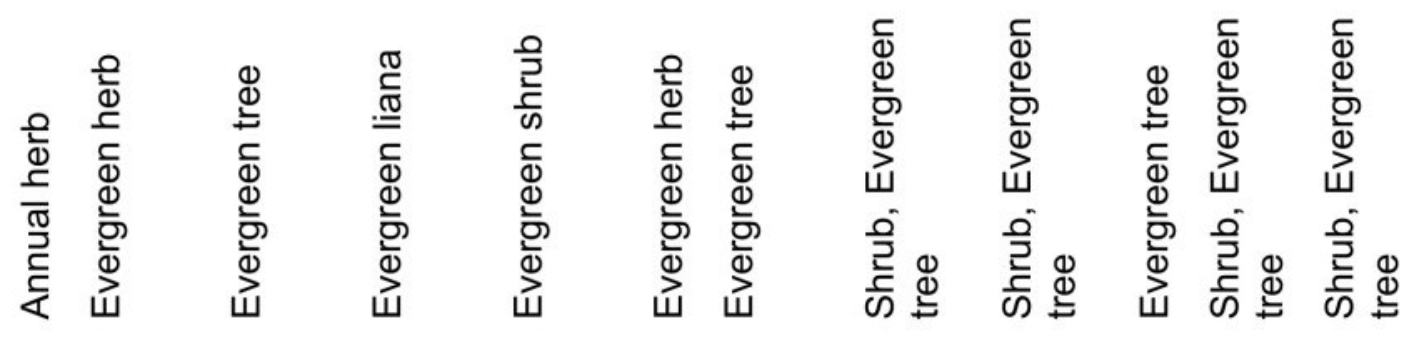

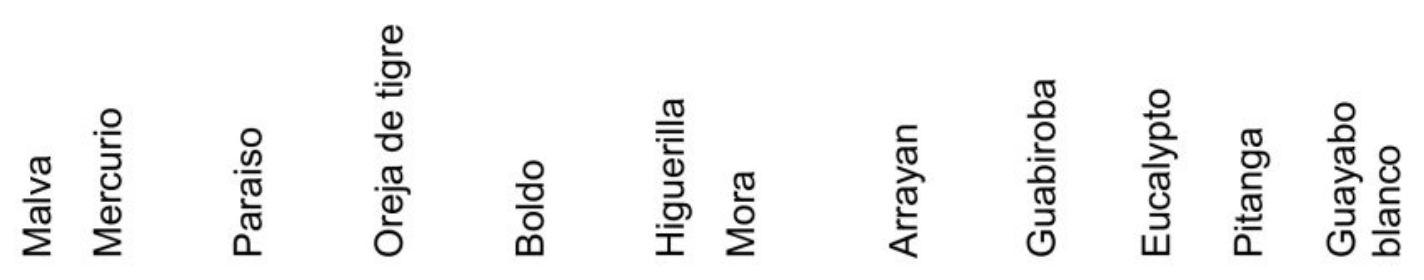

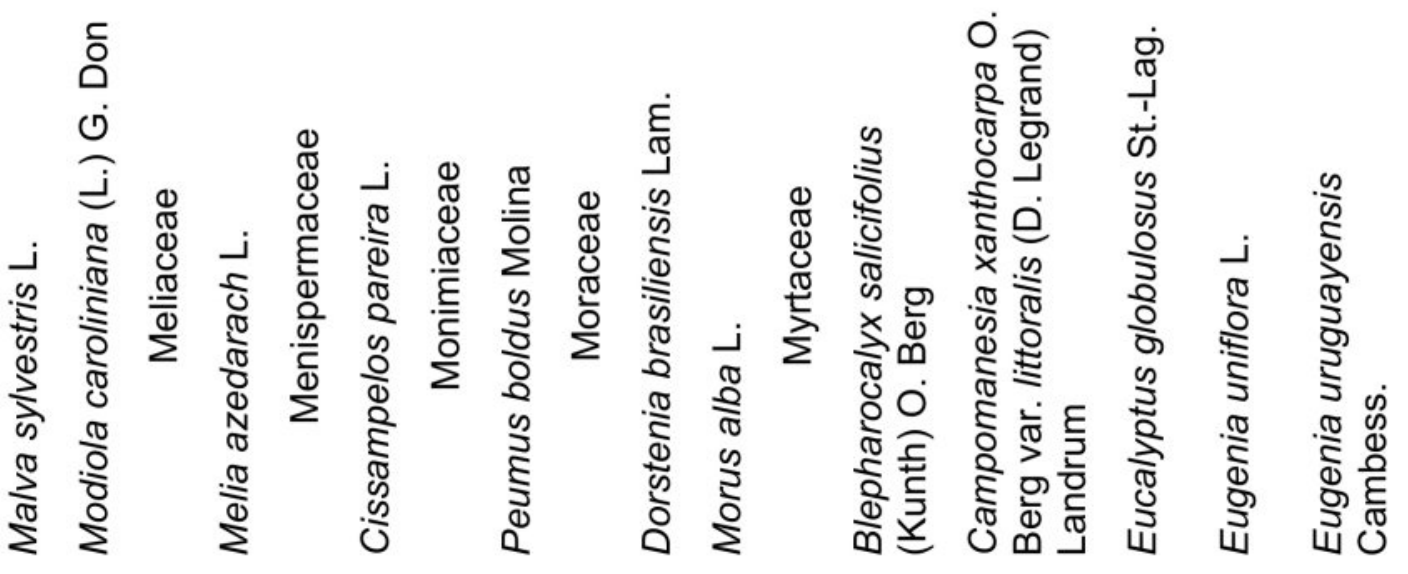




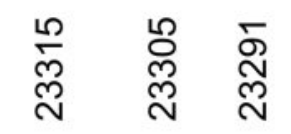

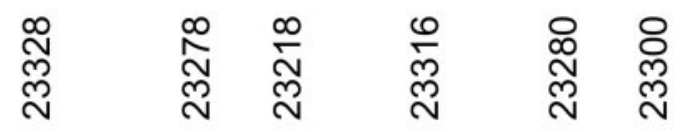

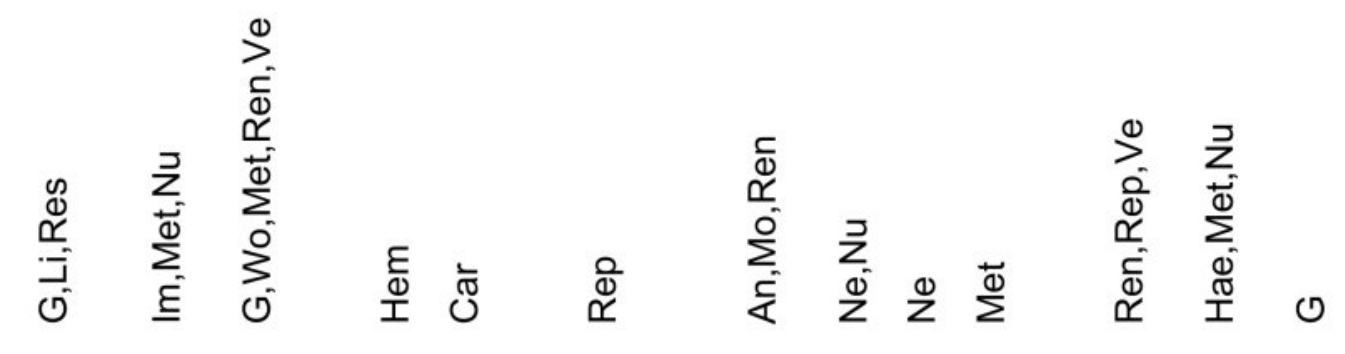

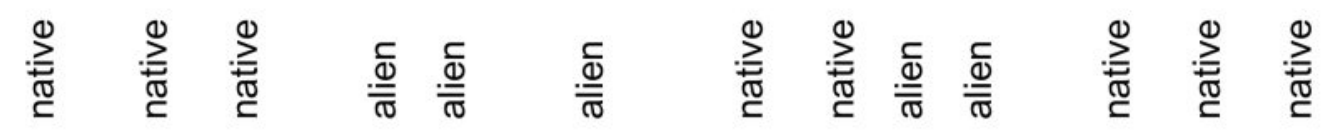

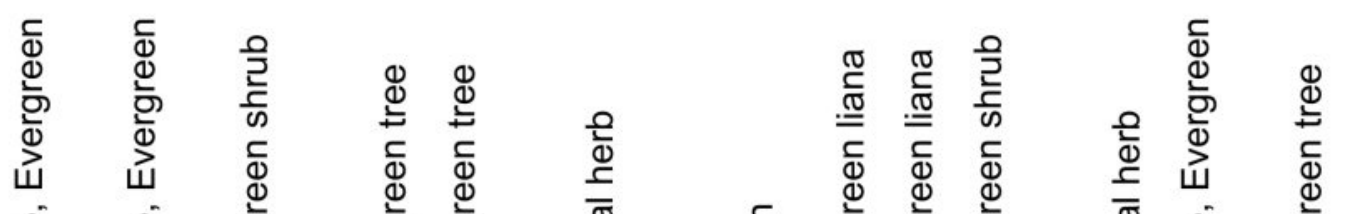

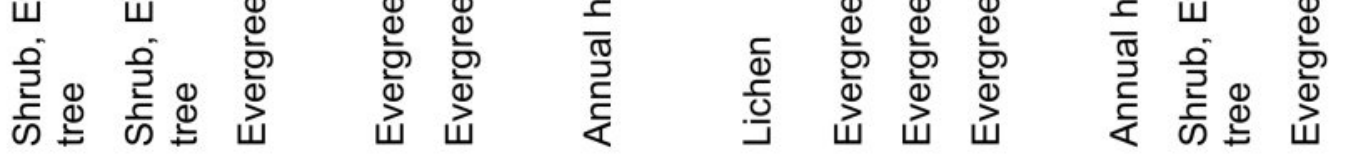

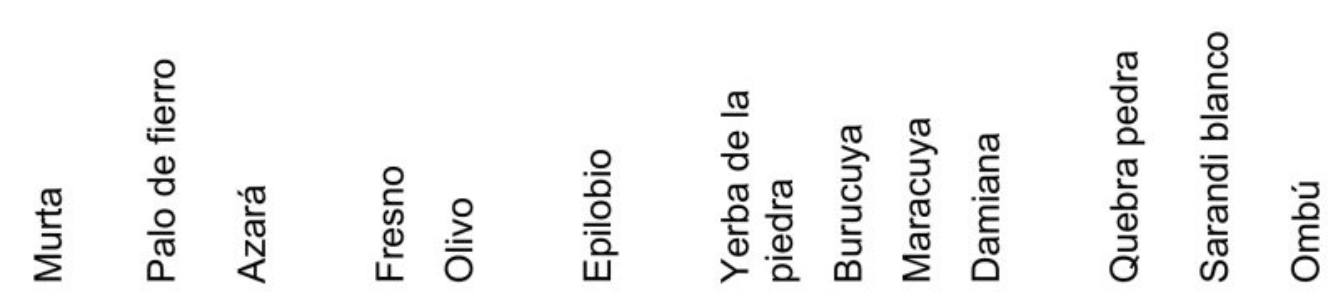

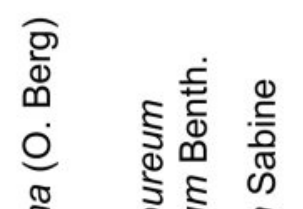

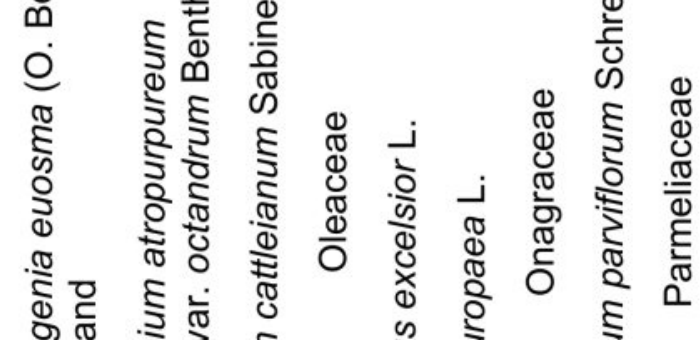

इำ 


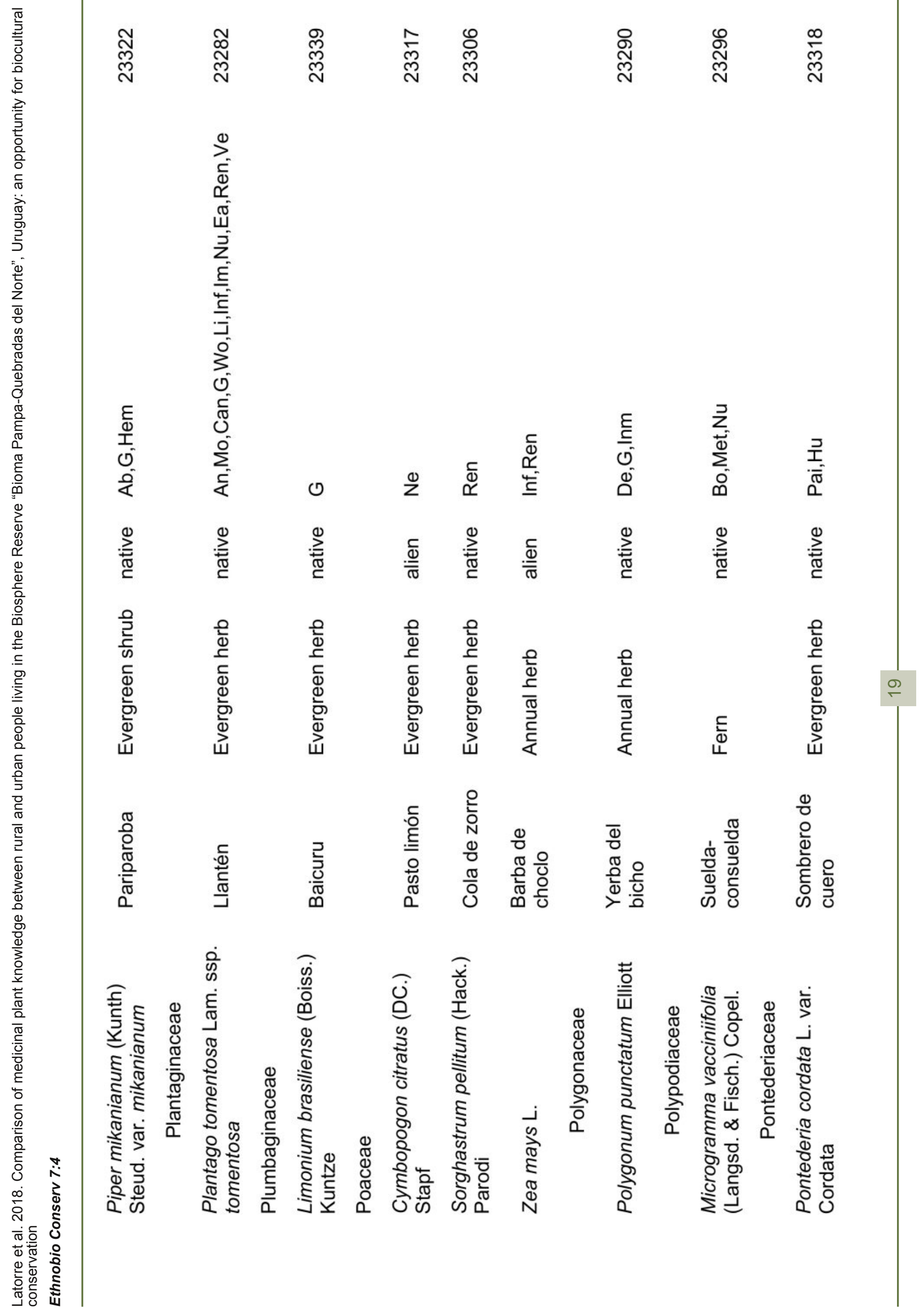


$\begin{array}{lll}\bar{N} & \bar{N} & \bar{N} \\ \text { N } & \text { N }\end{array}$

స్ల్ల

일

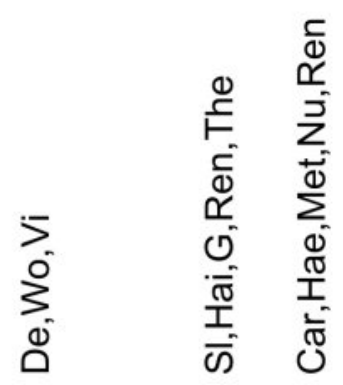

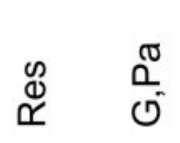

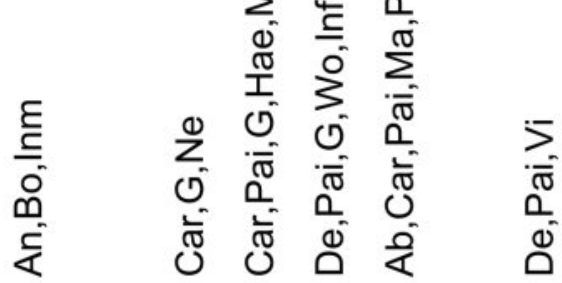

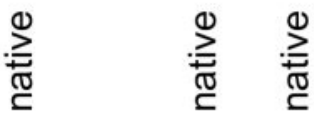

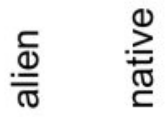

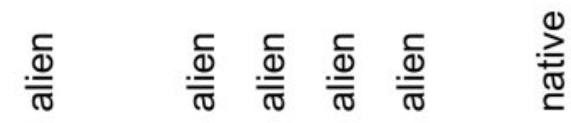

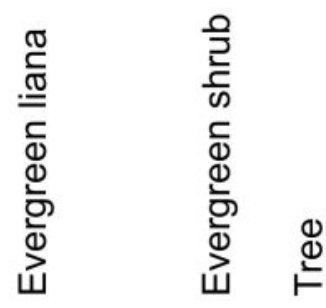

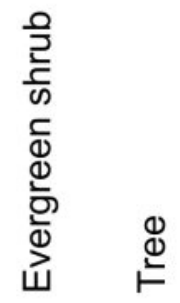

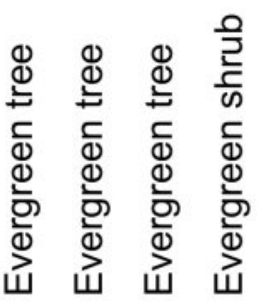

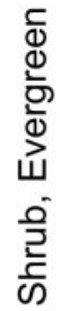

$\frac{0}{\frac{0}{2}}$

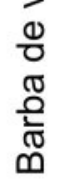

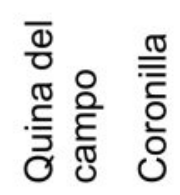

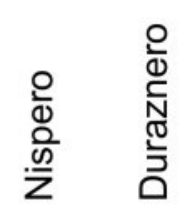

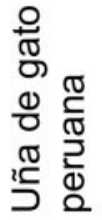

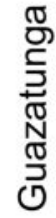

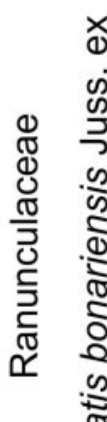

×

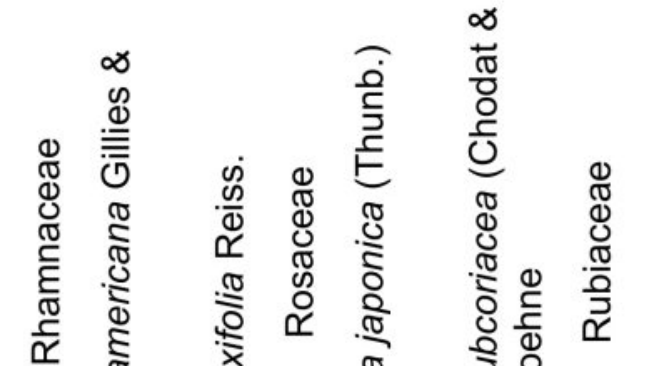

离 के

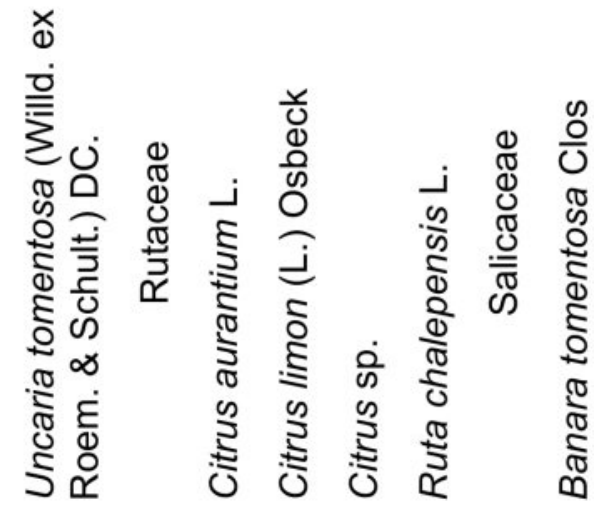

事

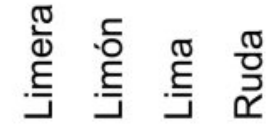

हैं

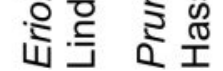


ஸे.

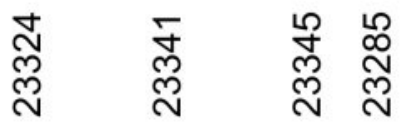
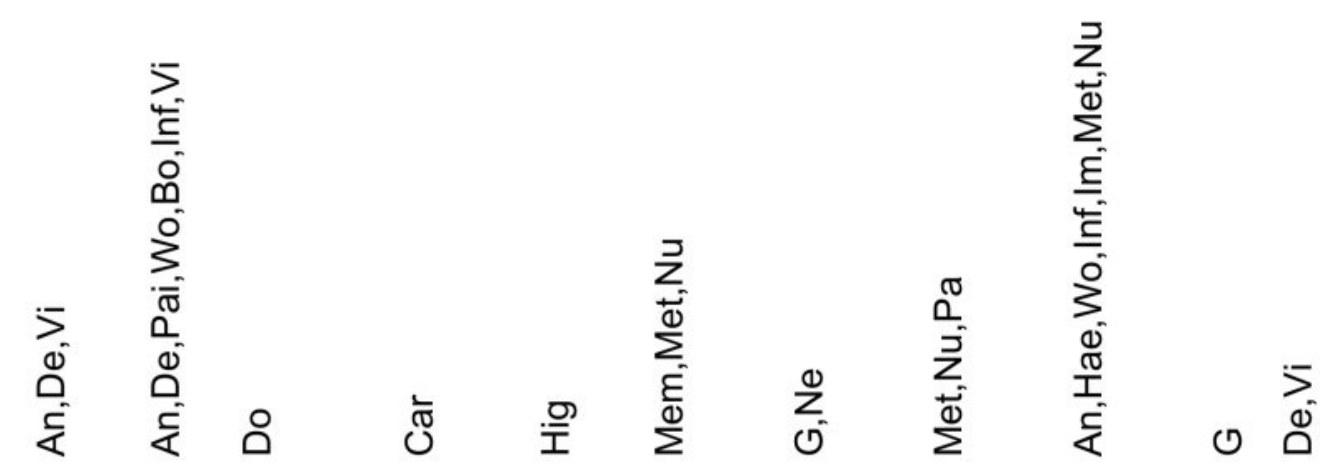

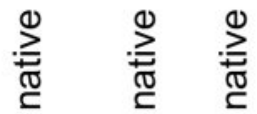

$\frac{\overline{\frac{\omega}{\sigma}}}{\frac{\mathrm{\sigma}}{\mathrm{\sigma}}}$

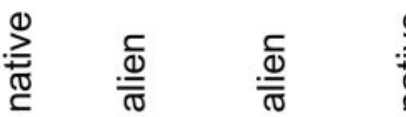

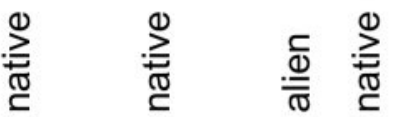

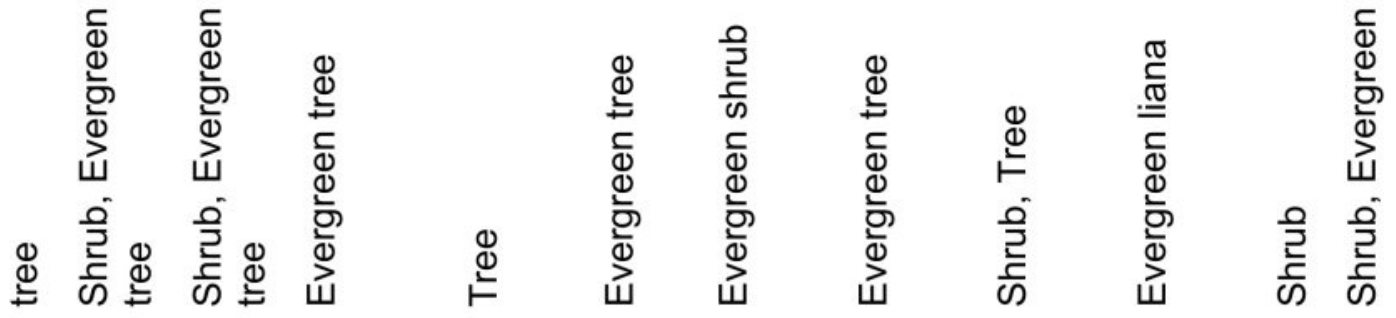

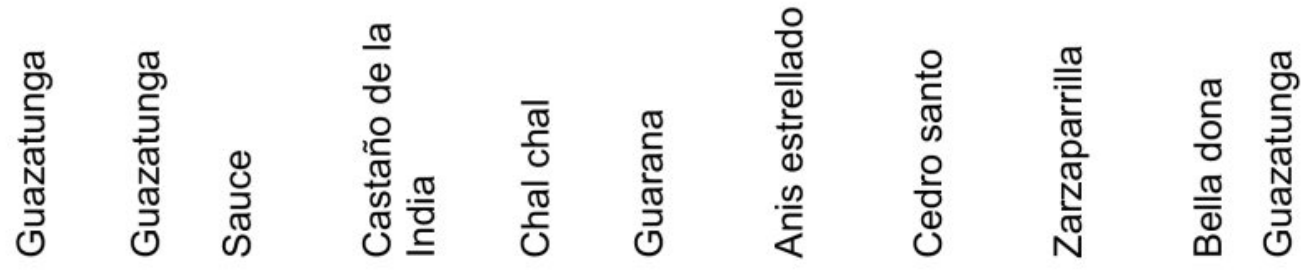

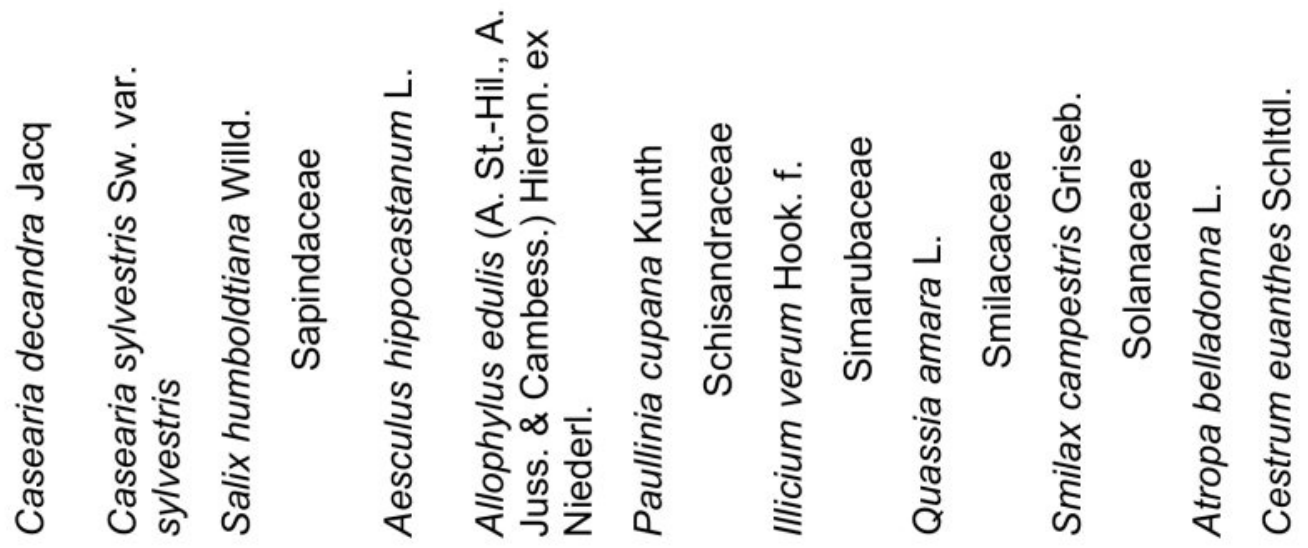




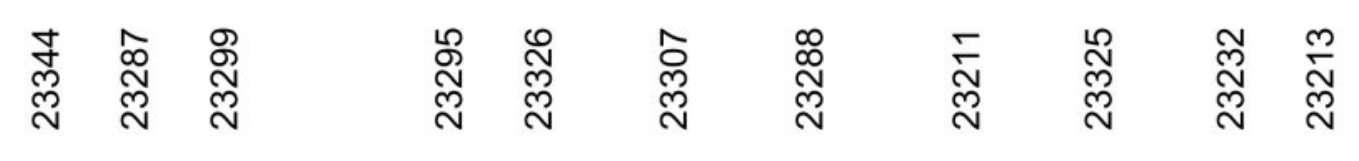

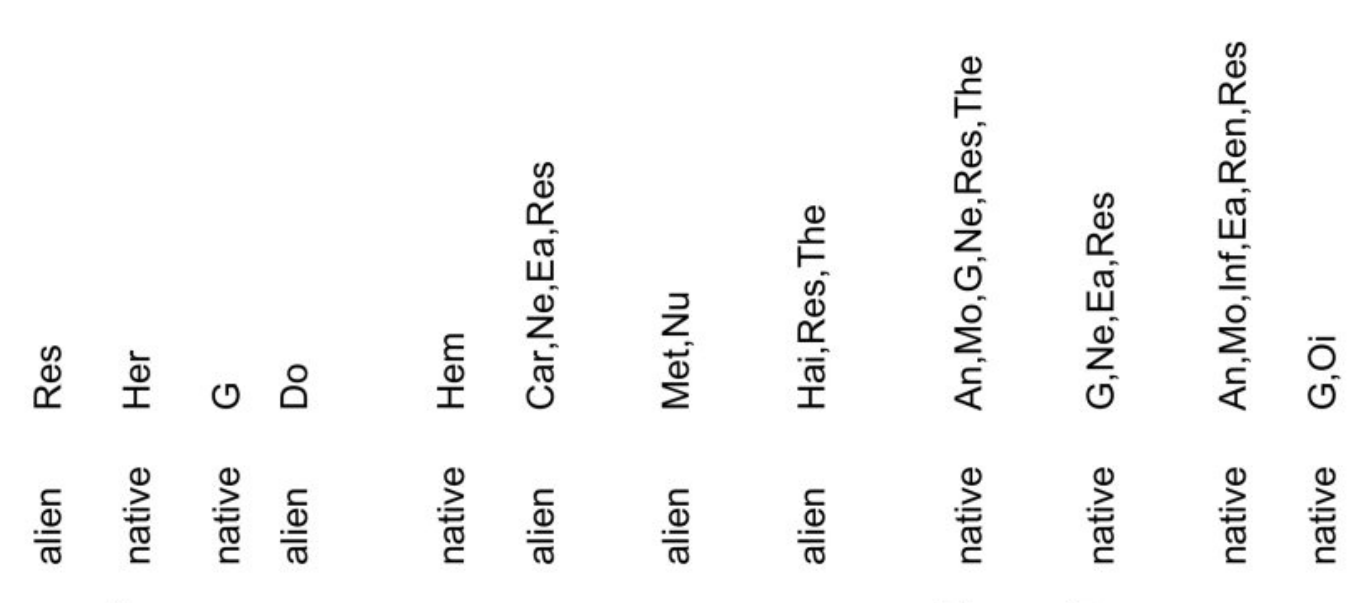

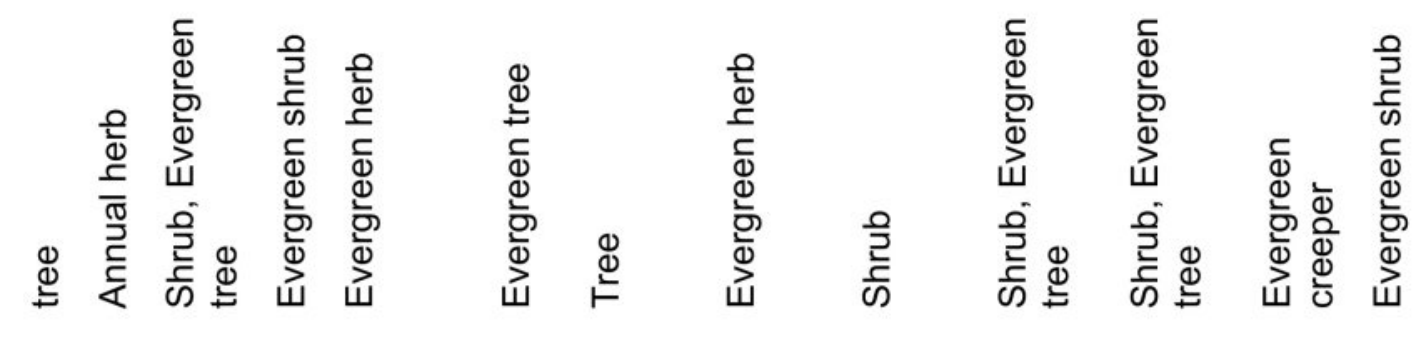

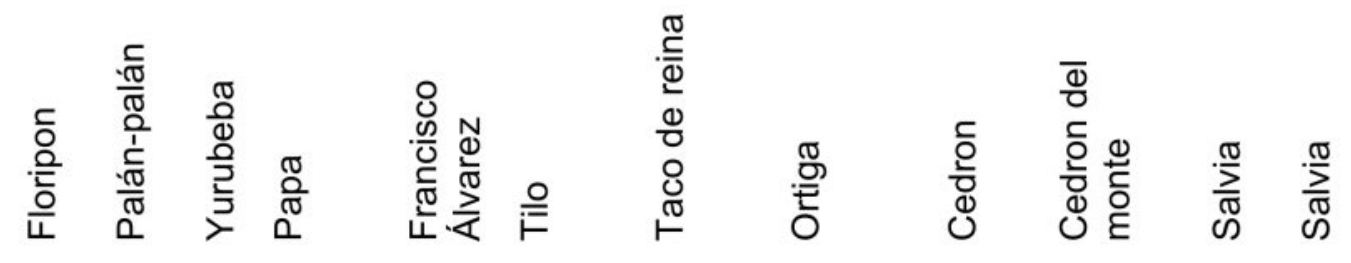

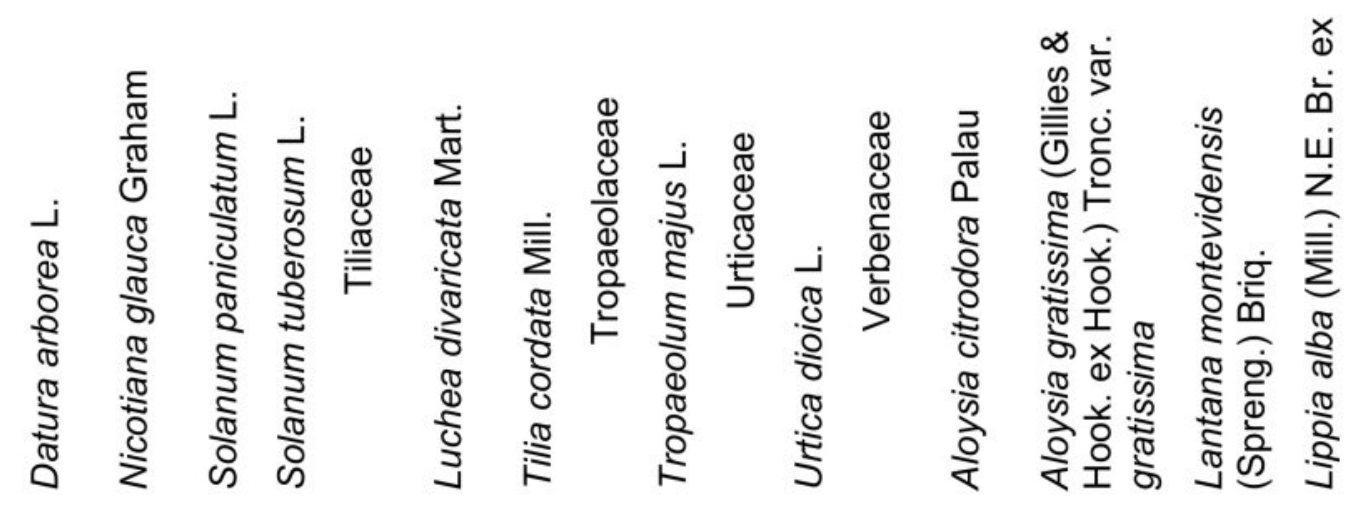




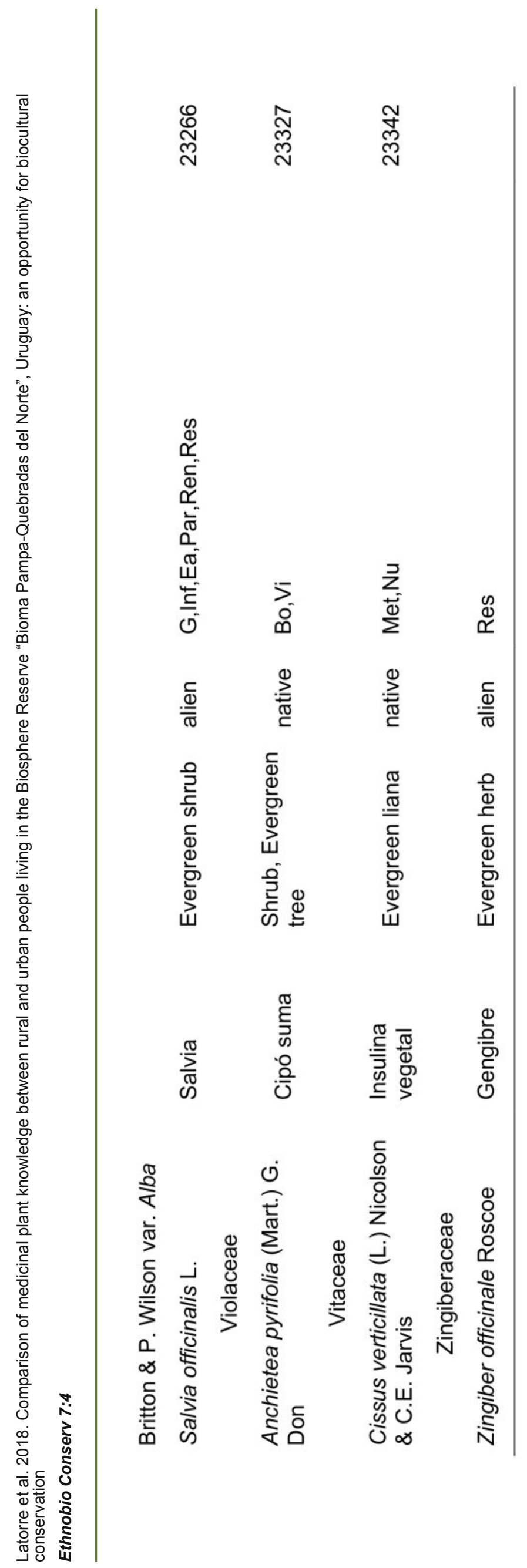




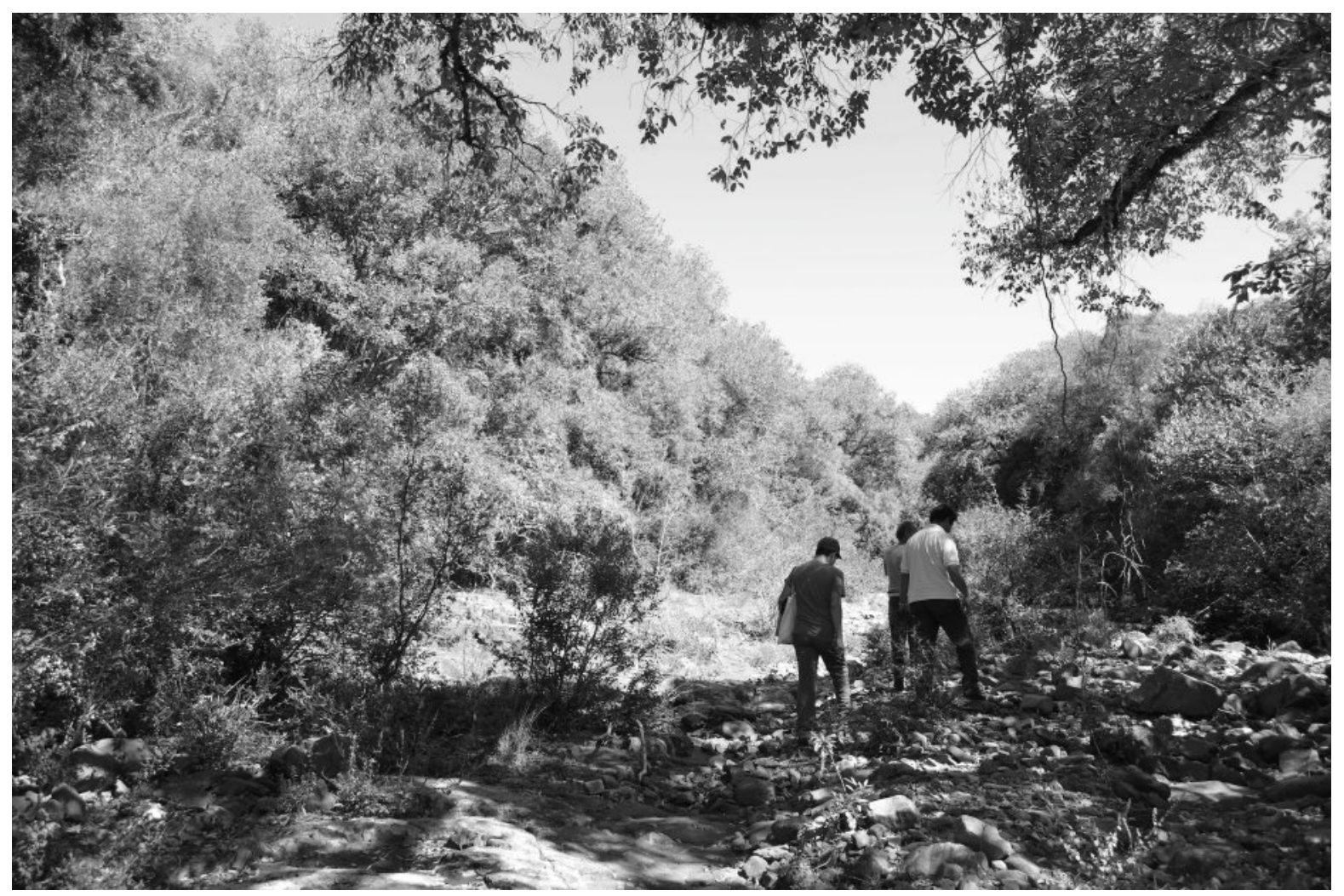

Figure 2: Walking and participant observation in medicinal plants harvesting near Lunarejo stream.

edulis, Ephedra tweediana, Jodina rhombifolia, Uncaria tomentosa, Scutia buxifolia (Table 1). It is important to highlight the harvest of Achyrocline satureioides. This medicinal plant is harvested on the "Palm Sunday" in Uruguay, which is located between the last week of March and the first weeks of April. On this religious date, people go to the sites where wild populations are found and collect a bouquet that will remain in the house throughout the year, being replaced next year, with the next harvest. It is highlighted that people consider that the species collected on this date has greater effectiveness (Fig. 3).

\section{Medicinal plants diversity}

We report a total of 159 species belonging to 75 botanical families used for medicinal purposes (Table 1). The richness estimated by the Chao 2 index was 195.6 species $\left(\mathrm{IC} 95 \%_{\text {sup }}=177 ; \mathrm{IC} 95 \%_{\text {inf }}=236\right)$. The diversity of botanical families were: Asteraceae with 24 species (40.0\%), followed by Lamiaceae and Myrtaceae with 8 species $(12.0 \%)$. The habit of growth is distributed in 79 species of trees, shrubs and sub-bushes $(49.7 \%), 61$ of herbs $(38.4 \%)$, seven of lianas $(4.4 \%)$, four of creepers $(2.5 \%)$, three of ferns $(1.9 \%)$, two bromeliads $(1.3 \%)$, a lichen $(0.6 \%)$, one succulent $(0.6 \%)$ and one cactus $(0.6 \%)$ (Table 1$)$. Of the total recorded species, 87 are native and 72 are alien. Regarding the comparison of the diversity of species used between urban and rural environments, it is found that when interpolating both curves to ten samples, the differences between the two groups are not significant (Fig. 4a). Regarding the geographic origin of the species, the native medicinal plants did not report a greater 


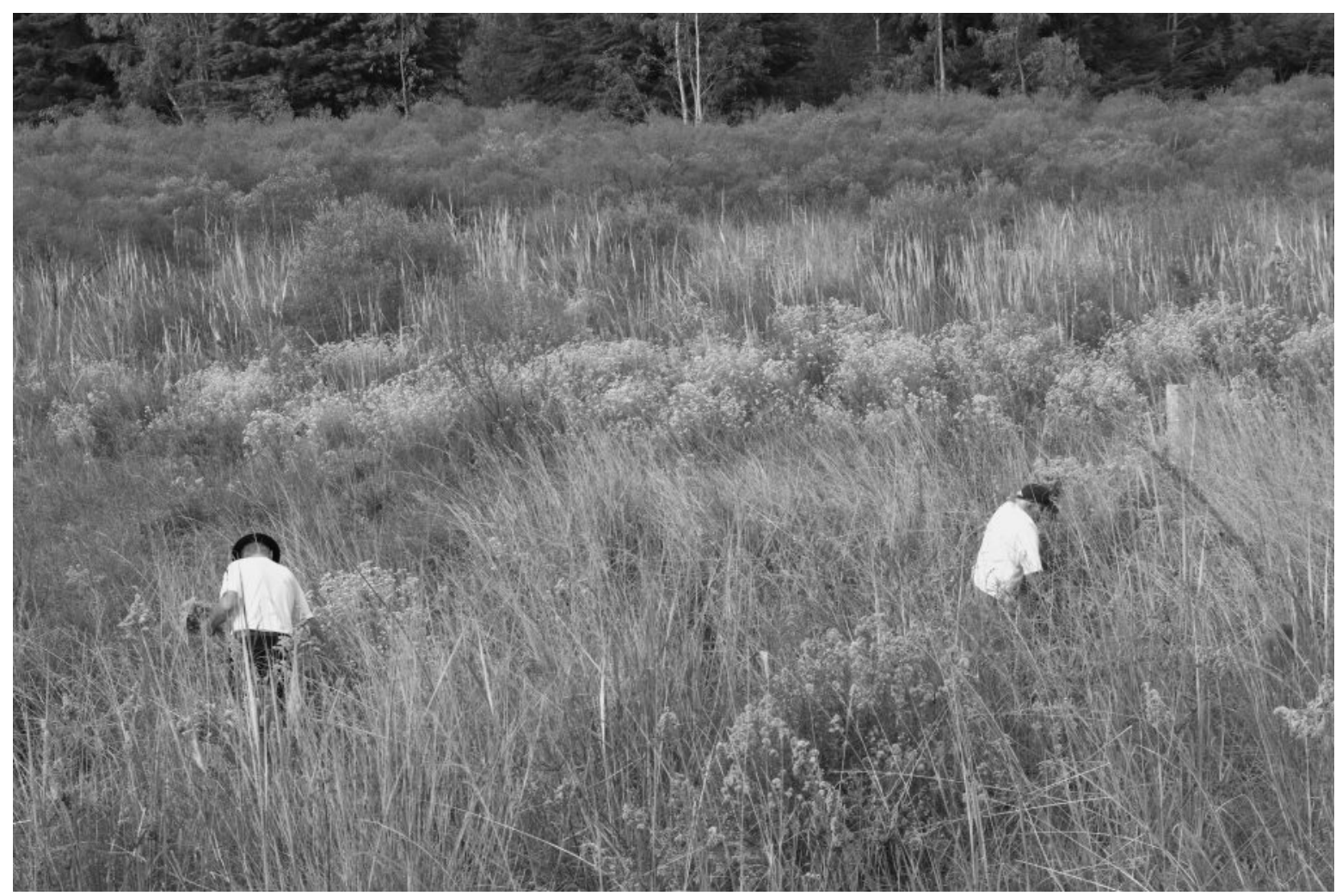

Figure 3: Harvesting of Achyrocline satureioides on the last Sunday of "Holy Week" in the vicinity of Rivera city, Rivera, Uruguay.

diversity than the alien ones for the whole sample (Fig. 4b). However, in discriminating the rural environments of the urban, the former reported a greater number of native medicinal plants (Fig. 4c) and the latter reported a greater number of alien medicinal plants (Fig. 4d).

\section{DISCUSSION}

This work represents the first contribution in which the herbalist of an area of relevance for the biocultural conservation in Uruguay is described. Considering the population density and the size of the Uruguayan territory, the diversity of medicinal plants included in the therapeutics of the studied community is surprising, but it is a reflection of vast herbalist knowledge in the context of the Neotropical region (see Arenas 2009; Begossi et al. 2002; Gazzaneo et al. 2005).
Asteraceae family has been the most conspicuous of the studied pharmacopoeia. This is expected since it corresponds to one of the families with the greatest diversity of genera and species within the Angiosperms (Funk et al. 2009), and also coincides with the surveys of diversity for the area (Brussa and Grela 2007). In addition, other works of the region describe this family as the most cited for medicinal uses (Baptista et al. 2013; Begossi et al. 2002). Species of Asteraceae family are pioneers and develop in open environments (Funk et al. 2009). Both traits could contribute to people finding, recognizing and harvesting them in places modified by anthropic activities, such as those corresponding to sites near houses, gardens and areas for agriculture and livestock. This finding reinforces what was observed by other authors regarding the importance of disturbed or modified 


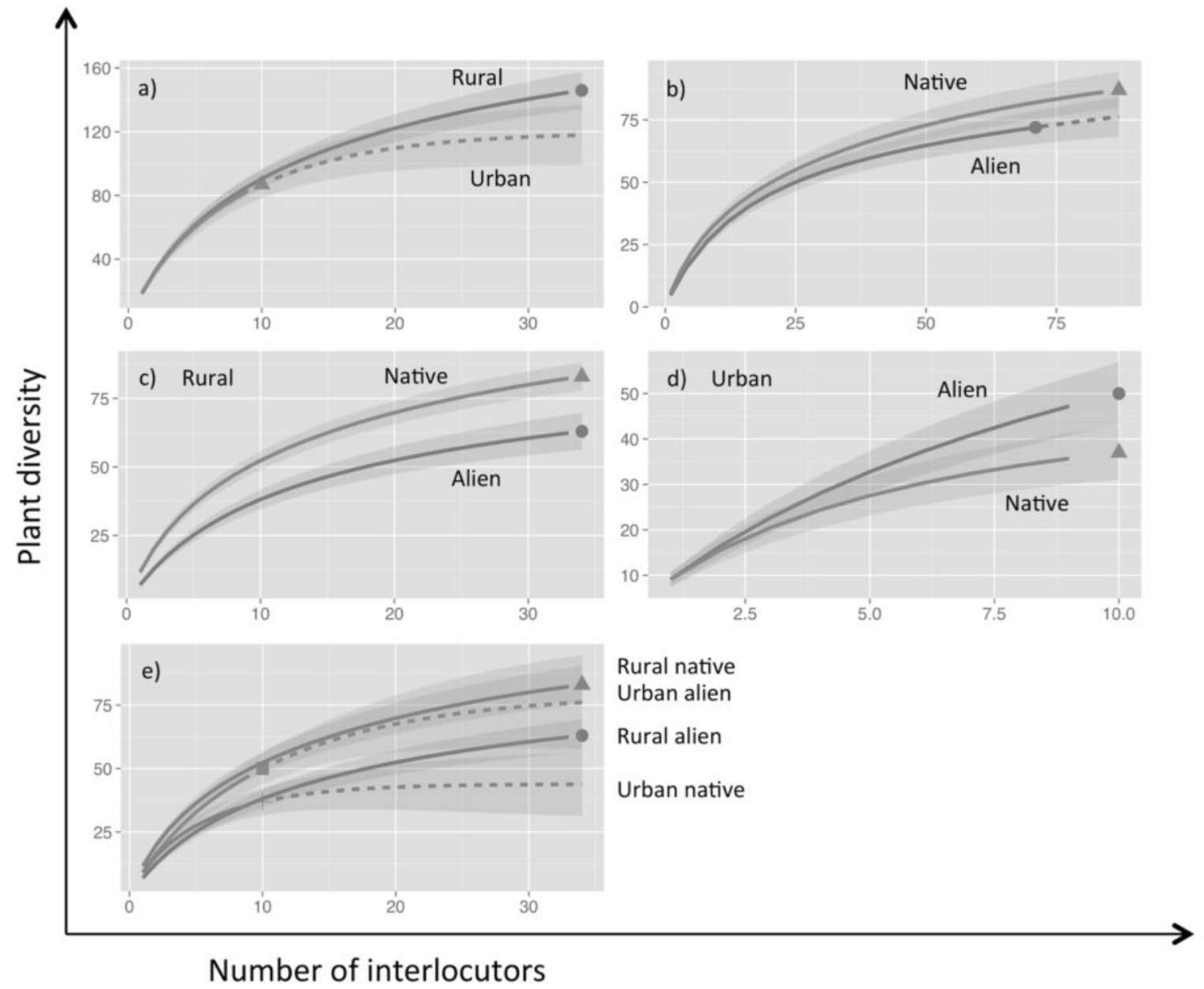

Figure 4: Rarefaction curves comparing the diversity of species reported for the interlocutors. a) Comparison for rural and urban environments; b) comparison according to provenance of the species in native and alien; c) Comparison of discriminated according to provenance of native and alien species reported exclusively in rural environment; d) discriminated comparison according to native and alien species reported exclusively in urban environment; e) comparison of diversity of species discriminated according to origin and environments.

environments and the role they play in the supply of medicinal resources (Begossi et al. 2002).

It is considered that the greater representativeness of Asteraceae, Lamiaceae and Myrtaceae is due in part to its organoleptic properties. These families are characterized by the presence of essential oils and strong flavor (Alonso Paz et al. 2008; Hurrell et al. 2011), which would prove to be a characteristic valued as a mnemonic resource for the identification, experimentation and use in treatments of various ailments (Casagrande 2000; Johns 1999). Thus these traits can influence the representativeness of these families as therapeutic options (Casagrande 2000; Pieroni and Torry 2007). A similar pattern has been reported in other works in Rio Grande do Sul and in the Atlantic Coastal Forest of South East Brazil (Bagatini et al. 2009; Begossi et al. 2002). 
Under deterministic or positivist theoretical frameworks that propose to the environment as a determinant and limiting factor, respectively, of the behaviors of resources choice and therapeutic options (Sutton and Anderson 2014), we could assume that in rural environments there is a greater knowledge and use of species richness than in urban ones, since in the latter the environment presents a lower species richness (Albuquerque 2013). This hypothesis was not supported by our data since no significant differences were observed when comparing the number of medicinal species mentioned by the interlocutors of rural or urban settlements. Some of the assumptions would not be observed at our study area: differences in environmental species richness and/or people knowledge on medicinal plants between rural and urban areas. In this sense, the environmental construction could change species availability (e.g. courtyards and homegardens), seeds interchange, purchase, and harvest and storage (e.g. harvest and storage of Achyrocline satureioides associated to religious calendar) (Kendal et al. 2011). The phenomenon should be considered together, including the various belief systems, knowledge and behavior, where people choose, use, share and actively manage a specific set of plants for the treatment of diseases and maintenance of health (Pochettino et al. 2012; Toledo 2002; Toledo and Alarcon-Chaires 2012).

When incorporating the origin of plant species that compose the botanical pharmacopoeia at the study area, a repertoire of medicinal plants composed by alien and native species is obtained, a characteristic shared by other works in South America (Abreu et al. 2015; Funk et al. 2009; Janni and Bastien 2004; Martínez and Pochettino 1992; Rossato et al. 1999). This pattern has been partly attributed to migration processes, which can be approached at two scales. On the one hand, a scale, with clear incidence of the Eurasian pharmacopoeia, legacy of the transatlantic migratory flow (Arenas 2009, Pellegrino 2013), which could explain the widespread presence of alien species. On the other hand, the second scale related to the rural population once established in a new urban context, recreates "landscapes of rural origin" in homegardens (Furlan et al. 2016). Following this reasoning it is possible to attribute the high number of mentions of alien to the characteristics of the population, with a strong component of descendants of European immigrants (Bonilla et al. 2004; Pellegrino 2013), while the mention of native plants in rural and urban environments could be related to the strong link between these environments (Medeiros et al. 2012). In this sense, different species of the family Asteraceae, such as Solidago microglossa and Stenachaenium campestre, in Brazil and Uruguay respectively, are known under the vernacular name of "Arnica". Possibly this is due to similarities in some of the characteristics of leaves and flowers with the species of European origin Arnica montana. Moreover, in the present work therapeutic purposes similar to those attributed to Arnica montana (e.g. wounds, muscle aches, bumps, bruises) are reported as Di Stasi and Hiruma-Lima (2002) did for the region of the Atlantic Forest.

In this regard, considering the idiosyncratic nature of the used plants, it was observed that in rural environments, unlike the urban ones, people tend to use a higher proportion of native than alien medicinal species. Greater familiarity with native medicinal plants in rural areas may be related to better access to harvest sites, 
obtaining "first-hand" medicinal resources (Pochettino et al. 2010, 2012). On the other hand, people in the urban environment would have difficulties with "first hand" access and would have a varied supply of medicinal plants thanks to third parties and where alien plants would be most represented (Balick and Cox 1996). In addition, in urbanized areas the incidence of modernization phenomena could be greater (e.g. greater access to the media, wide flow of people from diverse cultures), resulting in a more evident and fast incorporation of foreign plants for health care (e.g. Leonti 2011; Leonti et al. 2010). Possible agents influencing the dynamics of popular knowledge transformation in urban areas are: the greater choice of health care options, the difficult access to natural environments where the medicinal plants grow, and the processes of migration, acculturation and modernization (Alencar et al. 2014; Ceuterick et al. 2008; Medeiros et al. 2012; Ramirez 2007; Vandebroek and Balick 2012). The urban areas of the Rivera Department have a wide coverage of biomedical assistance, with availability of industrialized medicines. In rural areas, however, official assistance is not as frequent; nevertheless there is a system of sporadic medical rounds.

\section{CONCLUSIONS}

This work shows how community agents have a wealth of knowledge about plant diversity and phytotherapies. In urban and rural environments, the traditional knowledge of the Eurasian and Amerindian pharmacopoeias is reflected in the incorporation of alien and native plants. However, rural environments where the knowledge associated with the original peoples is more preserved, native species are predominant. The complexity of knowledge and behaviors associated with medicinal plants reflects the important role played by community referents in the maintenance and care of the health of the population as a whole. The results shown here can be used as tools to help policymakers to understand and to consider traditional knowledge and plant medicine. This knowledge should be integrated, as the strategic objectives of the World Health Organization (WHO 2013), into the new model of renewed Primary Health Care. It is particularly important in one of the most neglected areas of Uruguay. Development indices always show a relative disadvantage, in relation to the Uruguayan context, being considered as a marginalized society in terms of: poverty, social exclusion, marginality, gender inequality, instability and labor informality, among others indices (INE 2011; Rodriguez Miranda 2010). At the same time, the contribution offers a reflection that shows how environments with high biological diversity in multicultural contexts can constitute an ideal platform to address biocultural conservation efforts (Gavin et al. 2015; Maffi 2007).

\section{ACKNOWLEDGMENTS}

Authors acknowledge all of the interlocutors for the time that spent in the interviews, for having opened their homes and relied on our work. We thank Matías Arim for helpful comments and a careful lecture that have significantly improved the manuscript, and Anneliese Laten for contributions on English editing. ECL received two grants for this work, one from "Agencia Nacional de Investigación e Innovación (ANII), Uruguay, and other from the Rufford Small Grant Foundation. AC thanks FCE_2014_104763. 


\section{REFERENCES}

Abreu DBDO, Santoro FR, Albuquerque UP, Ladio AH, Medeiros PM (2015) Medicinal plant knowledge in a context of cultural pluralism: a case study in Northeastern Brazil. Journal of Ethnopharmacology 175:124-130.

Albuquerque UP (2006) Re-examining hypotheses concerning the use and knowledge of medicinal plants: a study in the Caatinga vegetation of NE Brazil. Journal of Ethnobiology and Ethnomedicine 2:30.

Albuquerque UP (2013) Etnobiologia. Bases ecológicas e evolutivas. 1ed. NUPEEA, Recife, PE, Brazil

Albuquerque UP, Vital LFCC, Lucena RFP, Alves RRN (2014). Methods and Techniques in Ethnobiology and Ethnoecology. Humana Press, Springer, New York

Albuquerque UP, Ramos MA, Lucena RFP, Alencar NL (2014) Methods and Techniques Used to Collect Ethnobiological Data. In: Albuquerque UP, Cunha LVFC, Lucena RFP, Alves RRN (eds) Methods and Techniques in Ethnobiology and Ethnoecology. 1 edn. Springer, New York, pp. 15-39.

Albuquerque UP, Silva JS, Campos JL, Sousa RS, Silva TC, Alves RRN (2013) The current status of ethnobiological research in Latin America: gaps and perspectives. Journal of Ethnobiology and Ethnomedicine 9:72.

Alencar NL, Sousa Araújo TA, Amorim ELC, Albuquerque UP (2010) The Inclusion and Selection of Medicinal Plants in Traditional Pharmacopoeias-Evidence in Support of the Diversification Hypothesis. Economic Botany 64:68-79.

Alencar NL, Santoro FR, Albuquerque UP (2014) What is the role of exotic medicinal plants in local medical systems? A study from the perspective of utilitarian redundancy. Revista Brasileira de Farmacognosia 24:506-515.

Alonso PE, Bassagoda MJ, Ferreira F (2008) Yuyos: uso racional de las plantas medicinales. Fin de Siglo, Montevideo

Arenas P (2009) Los estudios sobre medicina y farmacopea vernácula en el Gran Chaco. Rojasiana 8:81-100
Bagatini MD, Fachinetto JM, Silva ACF, Tedesco, SB (2009) Cytotoxic effects of infusions (tea) of Solidago microglossa DC. (Asteraceae) on the cell cycle of Allium cepa. Brazilian Journal of Pharmacognosy 19:632-636.

Balick MJ, Cox, PA (1996) Plants, people and culture: the science of ethnobotany. Freeman WH and Company: Scientific American Library, New York

Baptista MM, Ramos MA, Albuquerque UP, de Souza GC, Ritter MR (2013) Traditional botanical knowledge of artisanal fishers in southern Brazil. Journal of Ethnobiology and Ethnomedicine 9:54.

Barrios Pintos A (1963). Rivera en el ayer. De la crónica a la historia. Editorial Minas, Uruguay

Barrios Pintos A (1990) Rivera. Una historia diferente. Tomo II. Ministerio de Educación y Cultura, Montevideo.

Begossi A, Hanazaki N, Tamashiro JY (2002) Medicinal plants in the Atlantic forest (Brazil): knowledge, use, and conservation. Human Ecology 30:281-299.

Bennett BC, Prance GT (2000) Introduced plants in the indigenous pharmacopoeia of northern South America. Economic Botany 54:90-102.

Bennett BC, Balick MJ (2014) Does the name really matter? The importance of botanical nomenclature and plant taxonomy in biomedical research. Journal of Ethnopharmacology 152:387-392.

Bonilla C, Bertoni B, Gonzalez S, Cardoso H, Brum-Zorrilla N, Sans M (2004) Substantial Native American female contribution to the population of Tacuarembo, Uruguay, reveals past episodes of sex-biased gene flow. American Journal of Human Biology 16:289-297.

Brussa C, Grela I (2007) Flora arbórea del Uruguay. Con énfasis en las especies de Rivera y Tacuarembó. COFUSA, Montevideo

Cardona D, Acosta LD, Bertone CL (2013) Inequidades en salud entre países de Latinoamérica y el Caribe (2005-2010). Gaceta Sanitaria 27:292-297.

Casagrande DG (2000) Human taste and cognition in Tzeltal Maya medicinal plant use. Journal of Ecological Anthropology 4:57-69. 
Cardeillac J, Mascheroni P, Vitelli R (2016) Investigación sobre definición operativa de la población "rural" con fines estadísticos en Uruguay. (In: Instituto Nacional de Estadística, Uruguay)

[http://www.inmujeres.gub.uy/innovaportal/file/15 091/1/investigacion-sobre-definicion-operativade-la-poblacion-rural-con-fines-estadisticos-enuruguay.pdf] Accesed: 16 February 2018.

Ceuterick M, Vandebroek I, Torry B, Pieroni, A (2008) Cross-cultural adaptation in urban ethnobotany: the Colombian folk pharmacopoeia in London. Journal of Ethnopharmacology 120:342-359.

Colwell RK, Chao A, Gotelli NJ, Lin SY, Maol CX, Chazdon RL, Longino JT (2012) Models and estimators linking individual-based and sample-based rarefaction, extrapolation and comparison of assemblages. Journal of Plant Ecology 5:3-21.

Cunningham AB (2001) Applied ethnobotany. People, wild plant use and conservation. WWF, UNESCO, Royal Botanic Gardens, Kew

Curbelo C (2003) Analogy in historical archaeology. The case of San Francisco de Borja del Yi. The Socity for American Archaeology Archaeological Record 3:23.

Di Stasi LC, Hiruma-Lima CA (2002) Plantas medicinais na Amazônia e na Mata Atlântica. 2 ed. UNESP, São Paulo, Brazil

DINAMA (1998) Cuenca superior del arroyo Lunarejo. Dirección Nacional de Medio Ambiente, MVOTMA, Montevideo, Uruguay

DINAMA (1999) Propuesta de estrategia nacional para la conservación y uso sostenible de la biodiversidad biológica del Uruguay. Dirección Nacional de Medio Ambiente, MVOTMA, Montevideo, Uruguay

Eyssartier C, Ladio AH, Lozada M (2011) Traditional horticultural knowledge change in a rural population of the Patagonian steppe. Journal of Arid Environments 75:78-86.

Ferreira Júnior WS, Nascimento A, Alves RM, Medeiros PM, Soldati GT, Santoro FR, ReyesGarcía V, Albuquerque UP (2015) Resilience and Adaptation in Social-Ecological Systems. In: Albuquerque UP, Medeiros PM, Casas A (eds) Evolutionary Ethnobiology. Springer, New York, pp.105-119
Folke C, Carpenter SR, Walker B, Scheffer M, Chapin T, Rockström J (2010) Resilience thinking: integrating resilience, adaptability and transformability. Ecology and Society $15: 20$.

Fuentes G (2010) El sistema de salud uruguayo en la post dictadura: análisis de la reforma del Frente Amplio y las condiciones que la hicieron posible. Revista Uruguaya de Ciencias Políticas 19:119-142.

Funk VA, Susanna A, Stuessy TF, Robinson H (2009) Systematics, evolution \& biogeography of the Compositae. International Association for Plant Taxonomy, Vienna, Austria.

Furlan V, Kujawska M, Hilgert NI, Pochettino ML (2016). To what extent are medicinal plants shared between country home gardens and urban ones? A case study from Misiones, Argentina. Pharmaceutical Biology 209:1-13.

Gautreau P, Lezama F (2009) Clasificación florística de los bosques y arbustales de las sierras de Uruguay. Ecologia Austral 19:81-92.

Gavin MC, McCarter J, Mead A, Berkes F, Stepp JR, Peterson D, Tang R (2015) Defining biocultural approaches to conservation. Trends in Ecology \& Evolution 30:140-145.

Gazzaneo LRS, de Lucena RFP, Albuquerque UP (2005) Knowledge and use of medicinal plants by local specialists in an region of Atlantic Forest in the state of Pernambuco (Northeastern Brazil). Journal of Ethnobiology and Ethnomedicine 1:9.

González LR, Rodríguez Varese S (1990) Guaraníes y paisanos. Impacto de los indios misioneros en la formación del paisanaje. Editorial Nuestra Tierra, Montevideo

Gotelli NJ, Colwell RK (2001) Quantifying biodiversity: procedures and pitfalls in the measurement and comparison of species richness. Ecology Letters 4:379-391.

Gotelli NJ, Colwell RK (2010) Estimating species richness. In: A.E. Magurran and B.J. McGill (eds) Biological Diversity: Frontiers In Measurement And Assessment. Oxford University Press, Oxford, pp. 39-54.

Grela IA, Romero Suárez MF (1996) Estudio comparativo en dos sectores de monte de quebradas en el Arroyo Lunarejo, departamento de Rivera. UDELAR-Facultad de Agronomía, Montevideo 
Hilgert $\mathrm{NI}$ (2009) La salud en las Yungas. ¿Cuáles son los principales problemas según la medicina tradicional y la formal? In Vignale $\mathrm{N}$ D, Pochettino ML, (eds). Avances sobre plantas medicinales andinas. Argentina. RISAPRET/CYTED, Jujuy, Argentina

Hsieh TC, Ma KH, Chao A (2016) iNEXT: An R package for interpolation and extrapolation of species diversity (Hill numbers). Methods in Ecology and Evolution in press.

Hurrell JA (2014) Urban ethnobotany in Argentina: theoretical advances and methodological strategies. Ethnobiological Conservation 3:2

Hurrell JA, Pochettino ML (2014) Urban ethnobotany: theoretical and methodological contributions. In Albuquerque UP, Cunha LVF, Lucena RFP, Alves RRN (eds) Methods and techniques in ethnobiology and ethnoecology. Springer, New York, 293-309 pp.

Hurrell JA, Ulibarri E, Arenas PM, Pochettino ML (2011) Plantas de herboristería: plantas medicinales que se comercializan en herboristerías de la Ciudad de Buenos Aires. L.O.L.A, Buenos Aires, Argentina

IMM (2000) Flora Indigena. Curso de Conocimiento y Reconocimiento. Intendencia Municipal de Montevideo, Montevideo, Uruguay

INE (2011) Resumen operativo. Censos 2011. Instituto Nacional de Estadística, Uruguay

ISE (2003) Intellectual imperatives in ethnobiology. (In: International Society of Ethnobiology) [http://www.mobot.org] Accesedd: 23 October 2016.

ISE (2014) Codigo de Ética. (In: International Society of Ethnobiology) [http://www.ethnobiology.net] Accesedd: 11 December 2016.

Janni KD, Bastien JW (2004) Exotic botanicals in the Kallawaya pharmacopoeia. Economic Botany 58:S274-S279.

Johns $T$ (1999) The chemical ecology of human ingestive behaviors. Annual Review of Anthropology 28:27-50.

Kendal J, Tehrani JJ, Odling-Smee J (2011) Human niche construction in interdisciplinary focus. Philosophical transactions of the Royal Society of London. Biological Science 366:785792.
Kottek M, Grieser J, Beck C, Rudolf B, Rubel F (2006) World Map of the Koppen-Geiger Climate Classification Updated. Meteorologische Zeitschrift 15:259-263.

Leonti M (2011) The future is written: Impact of scripts on the cognition, selection, knowledge and transmission of medicinal plant use and its implications for ethnobotany and ethnopharmacology. Journal of Ethnopharmacology 134:542-555.

Leonti M, Cabras S, Weckerle CS, Solinas MN, Casu $L$ (2010) The causal dependence of present plant knowledge on herbalsContemporary medicinal plant use in Campania (Italy) compared to Matthioli (1568). Journal of Ethnopharmacology 130:379-391.

Lombardo A (1973) Plantas medicinales de la flora indígena. Banco de Seguros del Estado, Montevideo, Uruguay

Lombardo A (1979) Plantas medicinales de la flora indígena. Almanaque del Banco de Seguros del Estado. BSE, Uruguay. pp:103-113

Lozada M, Ladio AH, Weigandt M (2006) Cultural transmission of ethnobotanical knowledge in a rural community of northwestern Patagonia, Argentina. Economic Botany 60:374-85.

Maffi L (2007) Biocultural diversity and sustainability. In Pretty $J$ (ed) The Sage handbook of environment and society. Sage Publications, London, pp:267-275.

Maffi L, Woodley E (2010). Biocultural diversity conservation: a global sourcebook. Published Taylor \& Francis, UK \& USA

Martínez MR, Pochettino ML (1992) The "farmacia casera" (household pharmacy): a source of ethnopharmacological information. Fitoterapia 63:209-216.

Martínez MR, Pochettino ML, Crivos MA, Remorini C, Sy A (2006) Gathering and circulation of medicinal plants in a pluricultural context (Misiones, Argentina). Proceedings o the IVth International Congress of Ethnobotany (ICEB 2005).

Medeiros PM, Soldati GT, Alencar NL, Vandebroek I, Pieroni A, Hanazaki N, Albuquerque UP (2012) The use of medicinal plants by migrant people: adaptation, maintenance and replacement. EvidenceBased Complementary and Alternative Medicine $1-11$. 
Medeiros PM (2013) Why is change feared? Exotic species in local pharmacopoeias. Ethnobiology and Conservation 2:3.

MTSS (2017) Aportes para la evaluación de los lineamientos del Poder Ejecutivo para la sexta ronda de Consejos de Salarios. (In: Ministerio de Trabajo y Seguridad Social) [https://medios.presidencia.gub.uy/tav_portal/201 5/noticias/NO_Q506/AnalisisPautas.pdf].

Accesedd: 4 December 2016.

MVOTMA (2017) Sistema Nacional de Áreas Protegidas de Uruguay. (In: Ministerio de Vivienda Ordenamiento Territorial y Medio Ambiente)

[http://www.mvotma.gub.uy/portal/snap]

Accesedd: 26 May 2016.

Newman MEJ (2010). Networks. An introduction. Oxford University Press, New York.

Nolla SG, de Vargas M (2010) Diagnóstico socioeconómico zona URBAL-RIVERA, Uruguay. Programa Urbal Pampa, Uruguay.

Noy C (2008) Sampling knowledge: the hermeneutics of snowball sampling in qualitative research. International Journal of Social Research Methodology 11:327-344.

Pellegrino A (2013). Migraciones. Publicación Oficial del Bicentenario Montevideo, Uruguay.

Peroni N, Pereira AHF, Hanazaki N (2014) Ecological Methods in Ethnobotanical and Ethnobiological Research: Using Diversity Measurements and Richness Estimators. In: Albuquerque UP, VitalF. CCL, Lucena RFPD, Alves RRN (eds). Methods and Techniques in Ethnobiology and Ethnoecology. Humana Press, New York, pp. 397-412.

Pi Hugarte R (2014). Los indios del Uruguay. Ediciones de la Banda Oriental. Colección Heber Raviolo, Montevideo, Uruguay

Pi Hugarte R, Vidart D (1969) El legado de los inmigrantes. 1 ed. Editorial Nuestra Tierra, Montevideo, Uruguay

Pieroni A, Torry B (2007) Does the taste matter? Taste and medicinal perceptions associated with five selected herbal drugs among three ethnic groups in West Yorkshire, Northern England. Journal of Ethnobiology and Ethnomedicine 3:21.
Pochettino ML, Hurrell JA, Lema VS (2012) Local botanical knowledge and agrobiodiversity: homegardens at rural and periurban contexts in Argentina. Horticulture 105-132.

Pochettino ML, Ladio AH, Arenas PM (2010) Tradiciones y transformaciones en etnobotánica. CYTED Prog., Argentina.

R Core Team (2017) R: a language and environment for statistical computing (In: $\mathbf{R}$ Foundation for Statistical Computing, Vienna, Austria). [http://www.R-project.org] Accesedd: 22 February 2015

Ramirez CR (2007) Ethnobotany and the loss of traditional knowledge in the 21st century. Ethnobotany Research and Applications 5:245247.

Reyes-García V, Broesch J, Calvet-Mir L, Fuentes-Pelaez N, Mc. Dade TW, Parsa S, Tanner S, Huanca T, Leonard W, MartínezRodríguez M (2009) Cultural transmission of ethnobotanical knowledge and skills: an empirical analysis from an Amerindian society. Evolution and Human Behavior 30:27485.

Rodriguez Miranda A (2010) La frontera Uruguay-Brasil y el desarrollo local. Nóesis, Revista de Ciencias Sociales y Humanidades 19:16-51.

Rossato SC, Leitão HF, Begossi A (1999) Ethnobotany of Caiçaras of the Atlantic Forest coast (Brazil). Economic Botany 53:387395.

Rubel F, Kottek M (2010) Observed and projected climate shifts 1901-2100 depicted by world maps of the Köppen-Geiger climate classification. Meteorologische Zeitschrift 19:135-141.

Santoro FR, Ferreira Júnior WS, Araújo TAS, Ladio AH, Albuquerque UP (2015) Does plant species richness guarantee the resilience of local medical systems? A perspective from utilitarian redundancy. PLoS One doi:10.1371/journal.pone.0119826.

Sayagues L, Graf E, Delfino L (2000) Análisis de la inforamción publicada sobre composición florística de montes naturales del Uruguay. Agrociencia Uruguay 7:96-110.

Sollazzo A, Berterretche R (2011) El Sistema Nacional Integrado de Salud en Uruguay y los desafios para la Atencion Primaria. Ciencia \& Saude Coletiva 16:2829-2840. 
Soutullo A, Clavijo C, Martínez-Lanfranco JA (2013) Especies prioritarias para la conservación en Uruguay. Vertebrados, moluscos continentales y plantas vasculares. SNAP/DINAMA/MVOTMA y DICYT/ MEC, Montevideo, Uruguay

Sutton MK, Anderson E (2014) Introduction to cultural ecology. $3^{\circ}$ edition. Altamira, USA.

Toledo V (2002) Ethnoecology: A conceptual framework for the study of indigenous knowledge of nature. In: Stepp JR, Wyndham FS, Zarger R (eds). Ethnobiology and Biocultural Diversity: proceedings of the Seventh International Congress of Ethnobiology. Athens, GA, Georgia, USA, pp. 511-523
Toledo V, Alarcon-Chaires P (2012) La etnoecología hoy: panorama, avances, desafíos. Etnoecológica 9:1-16.

Vandebroek I, Balick MJ (2012) Globalization and loss of plant knowledge: challenging the paradigm. PLos One 7:5 doi: 10.1371/journal.pone.0037643

WHO. 2013. World Health Organization. Traditional Medicine Strategy 2014-2023. WHO Library Cataloguing-in-Publication Data, Hong Kong SAR, China.
Received: 05 February 2017

Accepted: 18 April 2017

Published: 01 March 2018 


\section{Eletronic supplementary 1 - Study area}

In the year 2011, 110.882 hectares of Rivera Department, Uruguay, is declared: "UNESCO Reserve Biosphere", under the name "Bioma Pampa-Quebradas del Norte" (Fig. S1).

Interview questions

Information of the interlocutor: name, age, place of birth and residence, work activity.

\section{Guiding questions}

1. Do you use medicinal plants for the maintenance and care of your health or your family?

2. What plants do you use and for what kind of treatment?

3. What plants cannot miss in your home?

4. Where do you get them?

5. If the interlocutor is the one who harvests, it is inquired about aspects of origin of the medicinal plants (forest, meadow, modified environments, courtyards, gardens).

6. Which type of preparations they perform for the consumption of MP?

7. In the case of sellers of medicinal plants, a modification of the questionnaire was made.

8. What plants cannot be missing in first aid kit and for what treatments?

9. Where do you get them?

10. Aspects related to the management of medicinal resources:

11. Harvest: site, frequency, harvest practice.

12. Preparation of the resource for sale: storage, drying, fragmentation, and packaging.

13. Finally, for both interviews, the origin of the information related to plants and treatments is investigated: source of learning (e.g., parental way, books, internet).

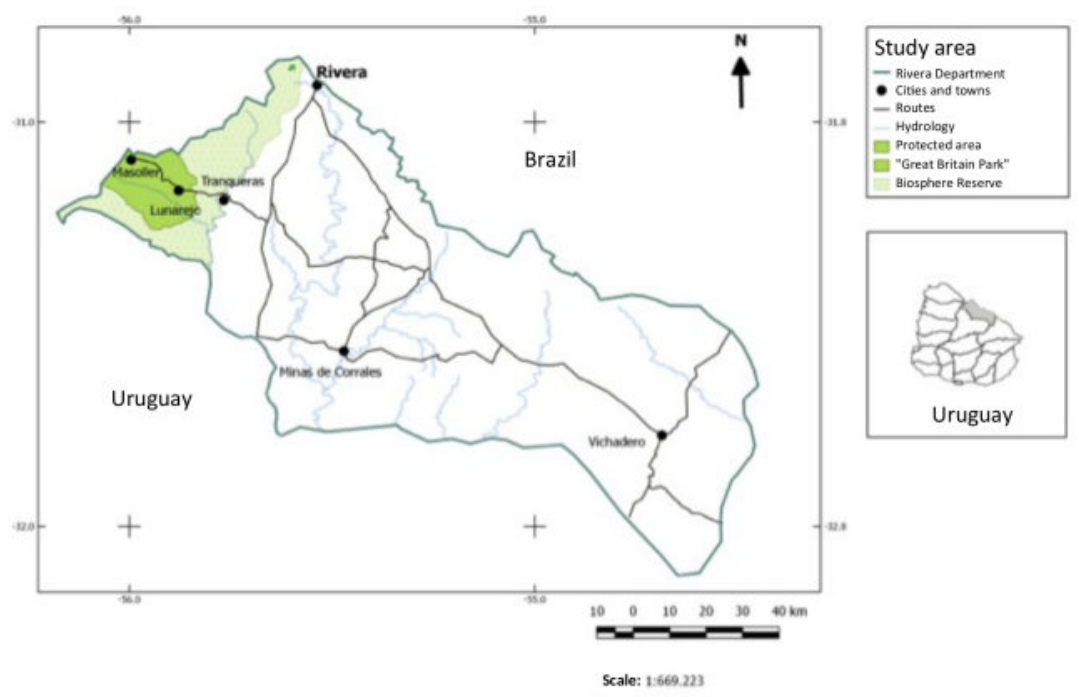

Figure S1: Map of the study area, at Rivera Department, Uruguay, in the national context and referencing the main localities and geographical features. 